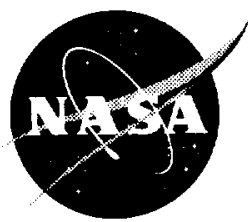

\title{
Flame Tube NOx Emissions Using a Lean-Direct-Wall-Injection Combustor Concept
}

Robert R. Tacina

Glenn Research Center, Cleveland, Ohio

Changlie Wey

QSS Group, Inc., Brook Park, Ohio

Kyung J. Choi

Drexel University, Philadelphia, Pennsylvania

Prepared for the

37th Joint Propulsion Conference and Exhibit

cosponsored by the AIAA, ASME, SAE, and ASEE

Salt Lake City, Utah, July 8-11, 2001

National Aeronautics and

Space Administration

Glenn Research Center 
Available from

NASA Center for Aerospace Information 7121 Standard Drive

Hanover, MD 21076
National Technical Information Service 5285 Port Royal Road Springfield, VA 22100

Available electronically at http://gltrs.grc.nasa.gov/GLTRS 


\title{
FLAME TUBE NOX EMISSIONS USING A LEAN-DIRECT-WALL- INJECTION COMBUSTOR CONCEPT
}

\author{
Robert R. Tacina* \\ National Aeronautics and Space Administration \\ Glenn Research Center \\ Cleveland, Ohio 44135 \\ Changlie Wey \\ QSS Group, Inc. \\ Brook Park, Ohio 44142 \\ Kyung J. Choi* \\ Drexel University \\ Philadelphia, Pennsylvania 19104
}

\begin{abstract}
A low-NOx emissions combustor concept has been demonstrated in flame tube tests. A lean-direct injection concept was used where the fuel is injected directly into the flame zone and the overall fuel-air mixture is lean. In this concept the air is swirled upstream of a venturi section and the fuel is injected radially inward into the air stream from the throat section using a plain-orifice injector. Configurations have two-, four-, or six-wall fuel injectors and in some cases fuel is also injected from an axially located simplex pressure atomizer. Various orifice sizes of the plain-orifice injector were evaluated for the effect on NOx. Test conditions were inlet temperatures up to $810 \mathrm{~K}$, inlet pressures up to $2760 \mathrm{kPa}$, and flame temperatures up to $2100 \mathrm{~K}$. A correlation is developed relating the NOx emissions to inlet temperature, inlet pressure, fuel-air ratio and pressure drop. Assuming that 15 percent of the combustion air would be used for liner cooling and using an advanced engine cycle, for the best configuration, the NOx emissions using the correlation is estimated to be $<75$ percent of the 1996 ICAO standard.
\end{abstract}

\section{INTRODUCTION}

Engines in most commercial aircraft today meet the current 1996 International Civil Aviation Organization, (ICAO) landing-takeoff NOx characteristic level, LTO NOx, limits with some margin. Concerns, however, are increasing about the effect of cruise NOx emissions on the ozone layer and global warming. Landing fees based on NOx emissions are being assessed by Sweden and Switzerland and could become more common and possibly even limit the access to some countries or airports. Although an increase in overall engine efficiency from a higher engine pressure ratio decreases the amount of the greenhouse gases $\mathrm{CO}_{2}$ and $\mathrm{H}_{2} \mathrm{O}$, it also increases the amount of NOx. To ensure that the next generation of aircraft are as clean as possible, one of the NASA goals is to reduce NOx emissions of future aircraft by a factor of three within 10 years and a factor of five within 20 years. The purpose of this paper is to describe a method to reduce NOx emissions that could be applicable to a wide range of engines and pressure ratios.

NOx formation on the lean-side of stoichiometry is essentially an exponential function of flame temperature. The key to NOx reduction is to therefore, burn the fuel at the lowest possible flame temperature. This is not only equivalent to burning as lean as possible but also with as uniform a mixture as possible to avoid locally stoichiometric zones that produce high amounts of NOx. Lean, premixed, prevaporized (LPP) combustion satisfies these criteria and is commonly used in ground-power applications with great success in reducing NOx emissions. For an aircraft application, however, there are concerns with auto-ignition and flashback in the premixing zones because of higher pressures and temperatures associated with aircraft engines. Also, LPP systems are susceptible to acoustic instabilities (which is a major problem in groundpower applications as well).

An alternative to LPP schemes is lean-direct injection (LDI) combustion. An LDI system differs from an LPP system in that the fuel is injected directly into the flame zone and, thus, does not have a potential for auto-ignition or flashback. As the fuel is not premixed and prevaporized, it is, however, important to achieve fine atomization and mixing of the fuel and air, quickly and uniformly, so that

*AIAA member 
flame temperatures are low and NOx-formation levels near those of LPP systems. The potential for low-NOx LDI combustors has been demonstrated by Anderson, ${ }^{1}$ Alkabie and Andrews, ${ }^{2}$ Schaefer and Samuelsen, ${ }^{3}$ and Terasaki and Hayashi ${ }^{4}$. Tacina ${ }^{5}$ has shown that NOx emissions from an LDI combustor can approach those of LPP combustors.

In the LDI concept described in this report, fuel is injected into a swirling airflow from a fuel injector located on the combustor wall or mixer wall. This concept is called lean-direct-wall-injection. LDWI. Important aspects of this technique are: (1) a liquid jet should be utilized (not a thin-film, hollow-cone spray typical of a conventional pressure-swirl atomizer), and (2) the jet should be injected radially inward from the mixer wall toward the approaching swirling airflow at an inclined angle with respect to the radial direction. Choi. ${ }^{6}$ The advantage of the LDWI concept is its use of a swirling airflow both for atomizing the injected liquid jet(s) and for mixing the atomized spray(s) in a short period of time. In the case of coaxially injected sprays, the strong centripetal forces of swirling airflow tend to sustain the liquid droplets (or fuel vapor) inside the core recirculating zones, resulting in a relatively slow mixing process. In the LDWI mode, however, the swirling airflow abruptly breaks the liquid jet into small droplets and the droplets are mixed quickly, within $25 \mathrm{~mm}$ downstream of the injection point.

Another advantage of this concept is that an LDWI combustor uses a simple, plain-orifice, fuel injector, i.e., an orifice at the end of a fuel tube. Using simple fuel injectors has the potential of reducing maintenance problems such as clogging and coking, especially for advanced gas-turbine engines that operate at high inlet air temperatures and pressures.

In this paper. emission measurements are reported for a single module, in a 76.2- $\mathrm{mm}$ diameter flame-tube with uncooled ceramic-cast walls. The test conditions are inlet pressures up to $2760 \mathrm{kPa}$, inlet temperatures up to $820 \mathrm{~K}$ and flame temperatures up to $2100 \mathrm{~K}$. A correlation is developed relating the NOx emissions to inlet pressure, inlet temperature, fuel-air ratio and pressure drop.

\section{CONFIGURATIONS}

The basic configuration of the LDWI module tested is shown in Fig. 1 and is a design by Choi and Tacina. ${ }^{7}$ The air swirler has 12 blades with a $45^{\circ}$ blade angle. The outer diameter of the air swirler is $66 \mathrm{~mm}$ and the inner diameter is $36.6 \mathrm{~mm}$. The Venturi section has a $44-\mathrm{mm}$ diameter throat and $\mathrm{a} 45^{\circ}$ wall-angle upstream and downstream of the throat. The fuel injectors are located $8 \mathrm{~mm}$ upstream of the throat.
Table 1 lists the seven variations to the basic configuration that were tested. The flow number. defined as fuel flow rate in $\mathrm{kg} / \mathrm{s}$ divided by the square root of the product of fuel differential-pressure in $\mathrm{Pa}$ and fuel density in $\mathrm{kg} / \mathrm{m}^{3}$, was measured for each configuration and is given in dimensions of $\mathrm{mm}^{2}$. The discharge coefficient is the flow number multiplied by the square root of two (which equals the effective area) divided by physical area. Configuration D, Fan-Spray, had a fuel injector that consisted of an elliptical slot. Of the four Fan-Spray injectors two have slot dimensions of $0.381 \times 1.778 \mathrm{~mm}$ and two are $0.381 \times 1.524 \mathrm{~mm}$, with the short dimension in the circumferential direction and long dimension in the radial direction.

In Fig. 2 the Flow Number for the individual fuel injectors is plotted as a function of fuel orifice diameter.

\section{EXPERIMENTAL FACILITY}

A schematic of the experimental facility is shown in Fig. 3. The incoming combustion air is heated by a nonvitiated heat exchanger to a maximum temperature of $840 \mathrm{~K}$ and a maximum pressure of $3000 \mathrm{kPa}$. The flow is measured by a venturi meter, and fuel-flow rate is measured by a turbine meter. The fuel-injector module is mounted in a stainless-steel pipe with a $152-\mathrm{mm}$ inside diameter. The fuel-air mixture is injected into a flame tube that has a diameter of $76.2 \mathrm{~mm}$. The flame tube flow passage is made of zirconium ( $\mathrm{ZrO}), 12 \mathrm{~mm}$ thick, that is housed in a $152-\mathrm{mm}$ diameter pipe. The gap between the zirconium tube and the pipe is filled with an alumina $\left(\mathrm{Al}_{2} \mathrm{O}_{3}\right)$ casting. The outside of the pipe is cooled by a water coil. The test section is $300-\mathrm{mm}$ long, followed by a water-quench section and back-pressure valve. Gas sampling is done $203 \mathrm{~mm}$ from the fuel-injector exit except for configurations $D$ and $G$ for which the data were taken at $305 \mathrm{~mm}$ downstream. A three-hole, water-cooled probe was used with the holes equally spaced across the diameter of the flame tube. There is a single-hole traversing probes located at $102 \mathrm{~mm}$ from the fuel-injector exit for radial-profile measurements. The concentrations of $\mathrm{O}_{2}, \mathrm{CO}, \mathrm{CO}_{2}, \mathrm{HC}$ (as $\mathrm{CH}_{4}$ ), $\mathrm{NO}$, and $\mathrm{NO} x$ are measured by standard, gasanalysis procedures, $\mathrm{SAE}:{ }^{8}$ chemiluminescence for $\mathrm{NO}$, nondispersive infrared absorption for $\mathrm{CO}$ and $\mathrm{CO}_{2}$, flame ionization for $\mathrm{HC}$, and paramagnetic analysis for $\mathrm{O}_{2}$. The $\mathrm{NO}_{2}-\mathrm{NO}$ converter is calibrated using standard $\mathrm{NO}_{2}$ to verify that conversion efficiencies are $>96$ percent. The overall accuracy of the emission measurements are estimated to be within 90 percent. This is based on the repeatability of data when the same configuration was tested on different days and with at least one change of configurations between tests of the same configuration. 


\section{RESULTS AND DISCUSSION}

The NOx emissions are plotted versus the adiabatic flame temperature for each configuration in Fig. 4 at various test conditions. The NOx values are given in terms of the emission index, $\mathrm{g} \mathrm{NO}_{2} / \mathrm{kg}$ fuel, where the emissions of $\mathrm{NO}$ are calculated as $\mathrm{NO}_{2}$. Although the plots in the individual figures are shown at nominally the same inlet conditions. the EI's are corrected for small differences by the following:

$$
\begin{aligned}
& \text { EINOx }_{\text {plot }}=\left(\operatorname{EINOx}_{\text {actual }}\right)\left(\frac{\mathrm{P}_{3 . \text { plot }}}{\mathrm{P}_{3, \text { actual }}}\right)^{0.595} \\
&\left\{\exp \left(\mathrm{T}_{3, \text { plot }}-\mathrm{T}_{3, \text { actual }}\right)\right\}\left(\frac{\Delta \mathrm{P}_{\text {plot }}}{\Delta \mathrm{P}_{\text {actual }}}\right)^{-0.566}
\end{aligned}
$$

where "plot" refers to the condition labeled in the plot and "actual" refers to the test condition. These correction factors are based on a correlation developed at NASA based on many configurations tested in the Advanced Subsonic Technology (AST) Program, both from industry and NASA configurations. All the NOx data are plotted at conditions where the combustion efficiency is $>99.9$ percent. The adiabatic flame temperature is determined from the inlet conditions and the gas-sample fuel-to-air ratio. The NOx emissions for these plots are from the probe located $203 \mathrm{~mm}$ downstream of the fuelinjector face. The fuel-air ratio as determined by the emissions measurement is compared to the metered fuelair ratio and generally are within 5 percent of each other.

A number of effects can be observed from Fig. 4. First, the plot of the log of NOx Emission Index (EINOx) as a function of flame temperature is nearly linear for configurations $D$ to G but curves upwards for configurations A to C. Also the EINOx has a greater dependence on flame temperature for configurations $\mathrm{A}$ to $\mathrm{C}$. Finally, EINOx increases with increasing inlet temperature and pressure and decreases with increasing pressure drop (which is accomplished through increased airflow). These effects will be discussed in more detail in the paragraph on the data correlations.

Configurations $D$ to $F$ were tested with 2 fuel injectors flowing instead of all $4(810 \mathrm{~K}, 2070 \mathrm{kPa}, 4$ percent $\Delta \mathrm{P})$. As can be seen in Fig. 4 the NOx was significantly higher (approximately a factor of two at a flame temperature of $1800 \mathrm{~K})$.

In configurations $\mathrm{A}$ to $\mathrm{C}$ a center pressure-swirl atomizing fuel-injector was used with a flow number of
0.187 , where 20 percent of the fuel went to the center injector and 80 percent to the wall injectors. As can be seen in Fig. $4(a)$ to (c), the NOx emissions were significantly higher when the center injector was used. This indicates that the fuel-air mixing is not as uniform with the use of a center fuel-injector.

The EINOx for the various configurations are compared in Fig. 5 (for all fuel injectors flowing, i.e.. 6 injectors flowing in configuration $\mathrm{A}$ and 4 injectors flowing in configurations $\mathrm{B}$ to $\mathrm{G})$. The NOx emissions from configurations $D$ to $G$ are similar. Configurations $A$. to C have lower NOx emissions at lower flame temperatures but they have a greater dependence on flame temperature. At high flame temperatures $(>1900 \mathrm{~K})$, configurations B and $C$ have higher NOx emissions than D to G. The NOx emissions from configuration $A$ are lower than that of any other configuration at all conditions tested, although if the data is extrapolated to flame temperatures above $2100 \mathrm{~K}$ the NOx emissions would probably be higher than Configurations D to $\mathrm{G}$.

The effect of flow number on the NOx emissions is plotted in Fig. 6. The larger the flow number the smaller the pressure drop across the fuel injector and thus is a measure of the penetration of the fuel into the air stream. The NOx emissions are relatively insensitive to flow number above values of 0.241 . Below a flow number of 0.241 the NOx decreases with decreasing flow number except at the condition of $\mathrm{T}_{3}=810 \mathrm{~K}, \mathrm{P}_{3}=2760 \mathrm{kPa}$. $\mathrm{T}_{\mathrm{f}}=2000 \mathrm{~K}$ where the NOx was higher at a flow number of 0.201 than at a flow number of 0.241 . This indicates that greater penetration is achieved with a smaller flow-number injector and is beneficial. However it is not a simple matter of penetration because, as noted above when configurations $D$ to $F$ were tested with 2 fuel injectors flowing instead of all 4 , the NOx was substantially higher (approximately a factor of two at a flame temperature of $1800 \mathrm{~K}$ ) even though with only two fuel injectors flowing the penetration should be significantly greater.

Another factor that could affect mixing and NOx production is that, with smaller flow-number (smaller orifice) injectors, the drop sizes should be smaller for the same fuel flow. Smaller drops would follow the airflow more closely and evaporate more quickly, thus improving the fuel and air mixing.

In Fig. 7, NOx data is plotted using the correlation developed at NASA based on many configurations tested in the Advanced Subsonic Technology (AST) Program, both from industry and NASA configurations. The correlation uses the measured inlet conditions of temperature, pressure and fuel-air ratio, and the measured pressure drop to correlate the EINOx. 


$$
\begin{aligned}
& \text { EINOx }=\mathrm{CP}_{3}^{0.595} \\
& \qquad \exp \left(\frac{\mathrm{T}_{3}}{194}\right) \mathrm{FAR}^{1.688}\left(\frac{\Delta \mathrm{P}}{\mathrm{P}}, \%\right)^{-0.565}
\end{aligned}
$$

where $C$ is a constant determined from the regression analysis. $P_{3}$ is the inlet pressure in $k P a, T_{3}$ the inlet temperature in $K, F A R$ is the fuel-air ratio and $\triangle P / P$ is the pressure drop across the fuel injector in percent.

The correlation is plotted using the open-square symbols in Fig. 7. The correlation is a good fit for configurations $D$ to $G$ although there is some scatter with configuration $\mathrm{F}$. However, configurations $\mathrm{A}$ to $\mathrm{C}$ have a different dependence on flame temperature, as shown in Fig. 4. and thus require a different correlation.

The second correlation, solid-circle symbols, is a fit based on the data from configurations $A$ to $C$. (There was no improvement in a specific fit for configurations $D$ to $G$ compared to the AST correlation.) For configurations A and $C$ it was found that the effect of inlet pressure, inlet temperature and pressure drop is the same as in the AST correlation and the only change necessary was in the fuelair ratio term.

$$
\begin{aligned}
& \text { EINOx }=17580 \mathrm{P}_{3}^{0.595} \\
& \exp \left(\frac{\mathrm{T}_{3}}{194}\right) \mathrm{FAR}^{4.63}\left(\frac{\Delta \mathrm{P}}{\mathrm{P}}, \%\right)^{-0.565} \\
& \begin{array}{r}
\text { EINOx }=2750 \mathrm{P}_{3}^{0.595} \\
\exp \left(\frac{\mathrm{T}_{3}}{194}\right) \mathrm{FAR}^{1.688}\left(\frac{\Delta \mathrm{P}}{\mathrm{P}}, \%\right)^{-0.565}
\end{array}
\end{aligned}
$$

For configuration B it was also necessary to modify the terms involving inlet temperature and pressure drop to reflect an increased effect of inlet temperature and slightly decreased dependence of pressure drop.

$$
\begin{aligned}
& \text { EINOx }=9774 \mathrm{P}_{3}^{0.600} \\
& \qquad \exp \left(\frac{\mathrm{T}_{3}}{98}\right) \text { FAR }^{5.57}\left(\frac{\Delta \mathrm{P}}{\mathrm{P}}, \%\right)^{-0.500}
\end{aligned}
$$

It is interesting to note that with configurations $A$ to C, when the terms in the AST correlation for the effect of inlet temperature, pressure and pressure drop are used, the exponent for the fuel-air ratio term varies inversely with the flow number or fuel-injector orifice size. A greater dependence on flame temperature or fuel-air ratio suggests that configurations $A$ to $C$ are closer to a premixed flame than the AST configurations, and configurations D to $G$.
Also the dependence on flame temperature for configuration $\mathrm{A}$ to $\mathrm{C}$ is greater than that of premixed flames. A possible explanation is that at high flame temperatures burning occurs earlier in the mixing process.

Using the correlation from configuration $\mathrm{A}$, the ICAO landing-takeoff NOx characteristic level, LTO NOx, International Standards and Recommended Practices, ${ }^{9}$ (parameter that integrates emissions over a landing/takeoffcycle) is calculated and compared to the ICAO standards for 55:1 and 30:1 pressure-ratio engines using a hypothetical advanced engine cycle from the NASA Ultra Efficient Engine Technology program, see Tables 2 and 3. and typical low power NOx values. Here 15 percent of the air was assumed to be used for cooling for the large engines and 20 percent cooling for the regional engines. The LTO NOx numbers are 77 percent below the standards for large engines and 75 percent below the standard for regional size engines. Note that these are based on data from flame-tube experiments and may not be indicative of a real engine.

The combustion efficiency for all the configurations and various conditions are shown in Fig. 8. For all configurations and for the range of conditions with inlet temperatures between 700 and $810 \mathrm{~K}$, and inlet pressures between 1380 and $2760 \mathrm{kPa}$, the combustion efficiency is $>99.9$ percent for flame temperatures above $1600 \mathrm{~K}$. Since the purpose of this research is to determine the low NOx potential for LDWI, data was not taken at lower flame temperatures to determine the limits for high-efficiency operation. It is assumed that for low power operation, a center fuel injector would be used and separate development of the optimum center injector would be required.

For configurations $\mathrm{A}$ to $\mathrm{C}$, radial profiles of fuel-air ratio, $\mathrm{NOx}, \mathrm{CO}$ and combustion efficiency are shown in Fig. 9. The vertical profiles were taken at an axial location of $102 \mathrm{~mm}$ downstream of the module. For configuration $\mathrm{B}$, only one-half of the profile was taken because of problems with the traversing mechanism. For configurations $\mathrm{A}$ and $\mathrm{C}$, the fuel distribution (as shown by fuel-air ratio) is nearly uniform although it is not symmetrical, with the fuel-air ratio being lower near one wall. The variation is about +10 percent with the variation increasing to about -20 percent near one wall. The NOx and $\mathrm{CO}$ emissions varied in exactly the same way as the fuel distribution, i.e., where the fuel concentration is high the NOx and $\mathrm{CO}$ are high. The combustion efficiency varies inversely with $\mathrm{CO}$ and is essentially the mirror image of the $\mathrm{CO}$ plot.

From the profiles, the fuel distribution (as given by fuel-air ratio) is slightly more uniform for configuration $\mathrm{C}$ compared to that of A, i.e., a lower-root-mean-square of the differences from the mean. This should result in a lower EINOx for configuration C, however, the EINOx is significantly lower for configuration A. A possible 
explanation is that the rate of mixing was faster for configuration $A$ and that at the time of burning the fuel was more uniformly distributed for configuration A. Also, only one profile was taken and different distributions may have been found if other radial profiles were taken.

\section{SUMMARY AND CONCLUSIONS}

A low-NOx, lean-direct-wall-injection concept has been demonstrated in flame-tube tests. The fuel is injected directly into the flame zone and the overall fuel-air mixture is lean. In this concept, the air is swirled upstream of a venturi section and the fuel is injected radially inward into the air stream upstream of the throat using a plain-orifice fuel-injector. The configurations had two-, four-, or sixwall fuel-injectors and in some cases fuel was also injected from a simplex pressure atomizer located at the center of the air swirler. Various orifice sizes of the plain-orifice fuel-injector were evaluated for the effect on NOx production. Test conditions ranged from inlet temperatures up to $810 \mathrm{~K}$, inlet pressures up to $2760 \mathrm{kPa}$, and flame temperatures up to $2100 \mathrm{~K}$. The NOx levels were quite low for the best configuration. With the 6 fuel-injector array, at an inlet temperature of $810 \mathrm{~K}$, inlet pressure of $2760 \mathrm{kPa}$, pressure drop of 4 percent and a flame temperature of $1900 \mathrm{~K}$, the NOx emission index was $<9$. The NOx emission levels were lower with the 6-fuelinjector configuration than with the 4-injector configuration which were in turn lower than with the 2 injector configuration. With the 4-injector array flow number or orifice size was varied. Over the range tested, the NOx emissions increased as flow number increased from 0.169 to $0.241 \mathrm{~mm}^{2}$ and then remained relatively constant with an increase to $0.776 \mathrm{~mm}^{2}$. A correlation was developed relating the NOx emission index to inlet temperature, inlet pressure, fuel-air ratio and pressure drop. For the lowest NOx configuration, the correlation had the usual dependence on inlet pressure, inlet temperature and pressure drop, but the effect of fuel-air ratio was greater than is usually reported and more similar to that of a premixed combustor. For a 55:1 pressure-ratio engine, and assuming that 15 percent of the combustion air would be used for liner cooling in an advanced engine cycle, the NOx emission index from the configuration-A correlation was estimated to be $<77$ percent of the 1996 ICAO standard. For a 30:1 pressure ratio engine and assuming 20 percent cooling flow, it would be a 75 percent reduction from the ICAO standard.

\section{REFERENCES}

1. Anderson, D.N., (1981). Ultra Lean Combustion at High Inlet Temperatures, ASME Paper 81-GT-44. Gas Turbine Conference \& Products Show', Houston TX, 1981 .

2. Alkabie, H.S., Andrews, G.E., and Ahmad, N.T. (1988). Lean Low NOx Primary Zones Using Radial Swirlers, paper ASME 88-GT-245, ASME Gas Turbine and Aero Engine Congress and Exposition. Amsterdam, 1988.

3. Schaefer, S.W., and Samuelsen, G. S., (1998). A Liquid Fueled, Lean Burn. Gas Turbine Combustor Injector, Combustion Science and Technology, Vol. 139 , pp. $41-47$.

4. Terasaki, T., and Hayashi. S. (1995). Lean NonPremixed Combustion for Low-NOx Gas Turbine Combustor, Yokohama International Gas Turbine Congress, Yokohoma, 1995.

5. Tacina, R.R., (1990). Low NOx Potential of Gas Turbine Engines, AIAA Paper 90-0550, $28^{\text {th }}$ Aerospace Science Meeting, Reno NV, 1990.

6. Choi, K., Huh, J., and Tacina, R., (1998). Studies on Well-Stirred Mixing of Liquid Droplets in a Lean Direct Injection Mode, $11^{\text {th }}$ Annual Conference on Liquid Atomization and Spray Systems, ILASSAmerica 98. Cleveland, Ohio, Sacramenta, CA, pp. 273-277.

7. Choi, K. and Tacina, R., "Lean Direct Wall Fuel Injection Method and Devices," U.S. Patent (6.067.790), May 2000.

8. SAE ARP1533-"Procedure for the Calculation of Gaseous Emissions from Aircraft Turbine Engines." 1996.

9. International Standards and Recommended Practices, Environmental Protection, Annex 16 to the Convention on International Civil Aviation, Vol. II, Aircraft Engine Emissions, Second Edition-July 1993. 
TABLE 1 -CONFIGURATIONS

\begin{tabular}{|c|c|c|c|c|c|}
\hline Configuration & $\begin{array}{c}\text { Number } \\
\text { of wall } \\
\text { fuel } \\
\text { injectors }\end{array}$ & $\begin{array}{c}\text { Wall-fuel injector } \\
\text { orifice size. } \\
\mathrm{mm}\end{array}$ & $\begin{array}{c}\text { Wall-injector } \\
\text { flow number, } \\
\mathrm{mm}^{2}\end{array}$ & $\begin{array}{c}\text { Discharge } \\
\text { coefficient }\end{array}$ & $\begin{array}{c}\text { Center } \\
\text { injector } \\
\text { flow number. } \\
\mathrm{mm}^{2}\end{array}$ \\
\hline $\mathrm{A}$ & 6 & 0.457 & 0.169 & 0.729 & 0.187 \\
\hline $\mathrm{B}$ & 4 & 0.533 & 0.201 & 0.636 & 0.187 \\
\hline $\mathrm{C}$ & 4 & 0.610 & 0.241 & 0.583 & 0.187 \\
\hline $\mathrm{D}$ & 4 or 2 & 1.778 or $1.524 \times 0.381$ & 0.468 & 0.744 & ---- \\
\hline E & 4 or 2 & 0.838 & 0.482 & 0.617 & ---- \\
\hline $\mathrm{F}$ & 4 or 2 & 1.016 & 0.669 & 0.583 & ---- \\
\hline $\mathrm{G}$ & 4 & 1.181 & 0.776 & 0.501 & ---- \\
\hline
\end{tabular}

TABLE 2.-LARGE ENGINE CYCLE

\begin{tabular}{|l|c|c|c|c|c|c|}
\hline & $\begin{array}{c}\text { Power, } \\
\text { percent }\end{array}$ & $\begin{array}{c}\text { Time, } \\
\mathrm{min}\end{array}$ & $\begin{array}{c}\text { Pt3.0, } \\
\mathrm{kPa}\end{array}$ & $\begin{array}{c}\text { T3.0, } \\
\mathrm{K}\end{array}$ & $\Delta$ P/P & FARt \\
\hline SLTO & 100.0 & 0.7 & 5426 & 970 & 0.04 & 0.0289 \\
\hline Climb & 85.0 & 2.2 & 4709 & 934 & 0.04 & 0.0266 \\
\hline Approach & 30.0 & 4 & 2055 & 740 & 0.04 & 0.0157 \\
\hline Idle & 7.0 & 26 & 993 & 615 & 0.04 & 0.0093 \\
\hline
\end{tabular}

TABLE 3-REGIONAL ENGINE CYCLE

\begin{tabular}{|l|c|c|c|c|c|c|}
\hline & $\begin{array}{c}\text { Power. } \\
\text { percent }\end{array}$ & $\begin{array}{c}\text { Time. } \\
\mathrm{min}\end{array}$ & $\begin{array}{c}\mathrm{Pt3.0} \\
\mathrm{kPa}\end{array}$ & $\begin{array}{c}\mathrm{T} 3.0 . \\
\mathrm{K}\end{array}$ & AP/P & FARt \\
\hline SLTO & 100.0 & 0.7 & 3041 & 828 & 0.04 & 0.03190 \\
\hline Climb & 85.0 & 2.2 & 2655 & 792 & 0.04 & 0.02896 \\
\hline Approach & 30.0 & 4 & 1158 & 637 & 0.04 & 0.01998 \\
\hline Idle & 7.0 & 26 & 414 & 505 & 0.04 & 0.01515 \\
\hline
\end{tabular}




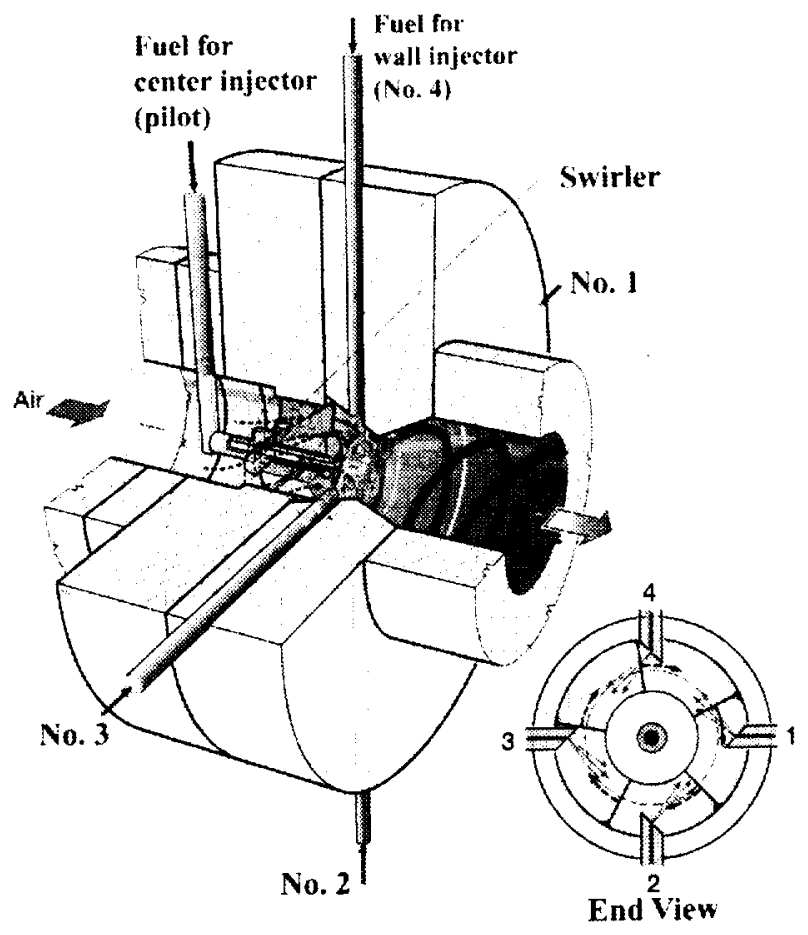

Figure 1. - Ultra low NOx combustion - lean direct wall injector

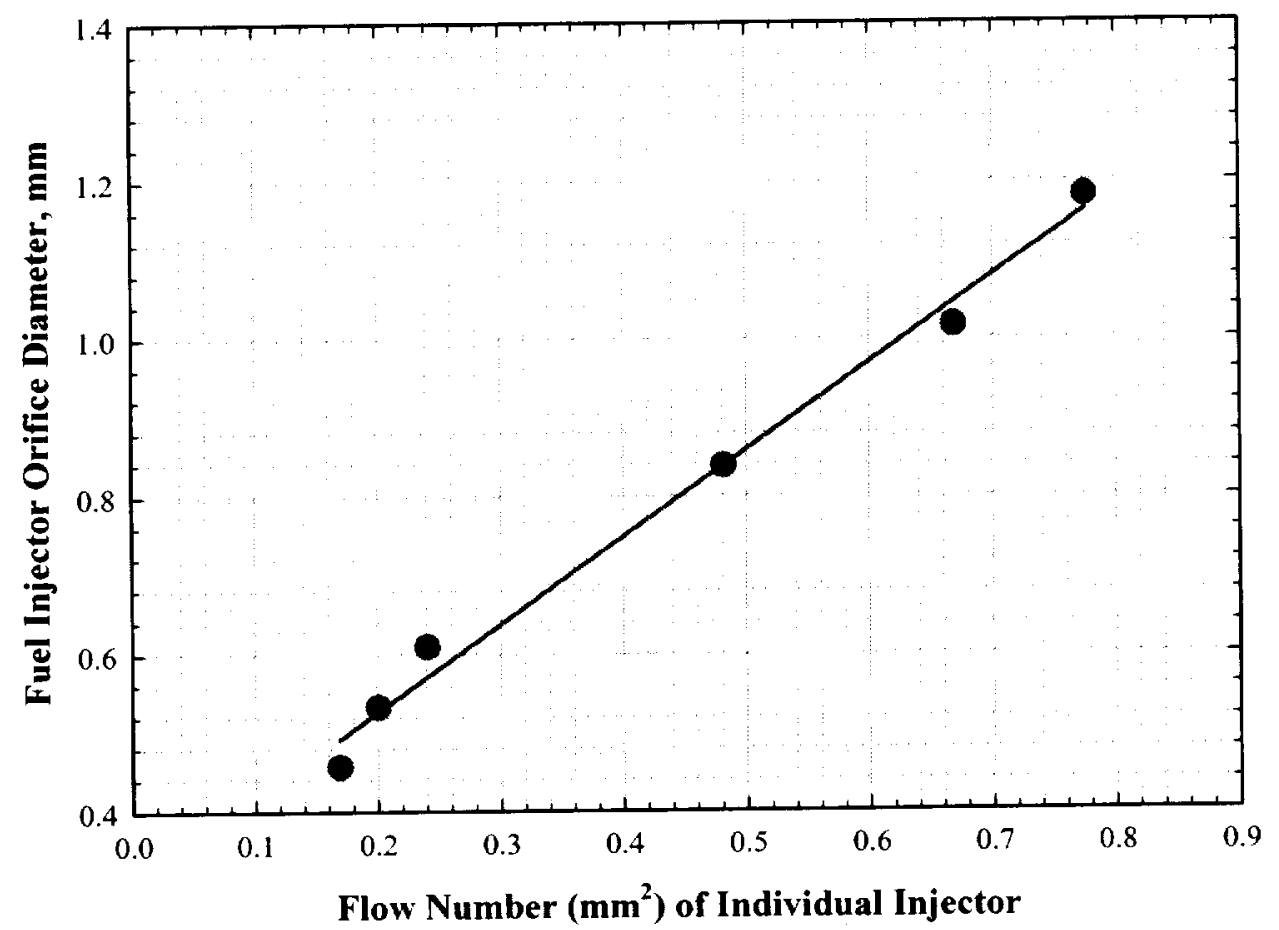

Figure 2. - Flow number as a function of fuel injector orifice diameter 


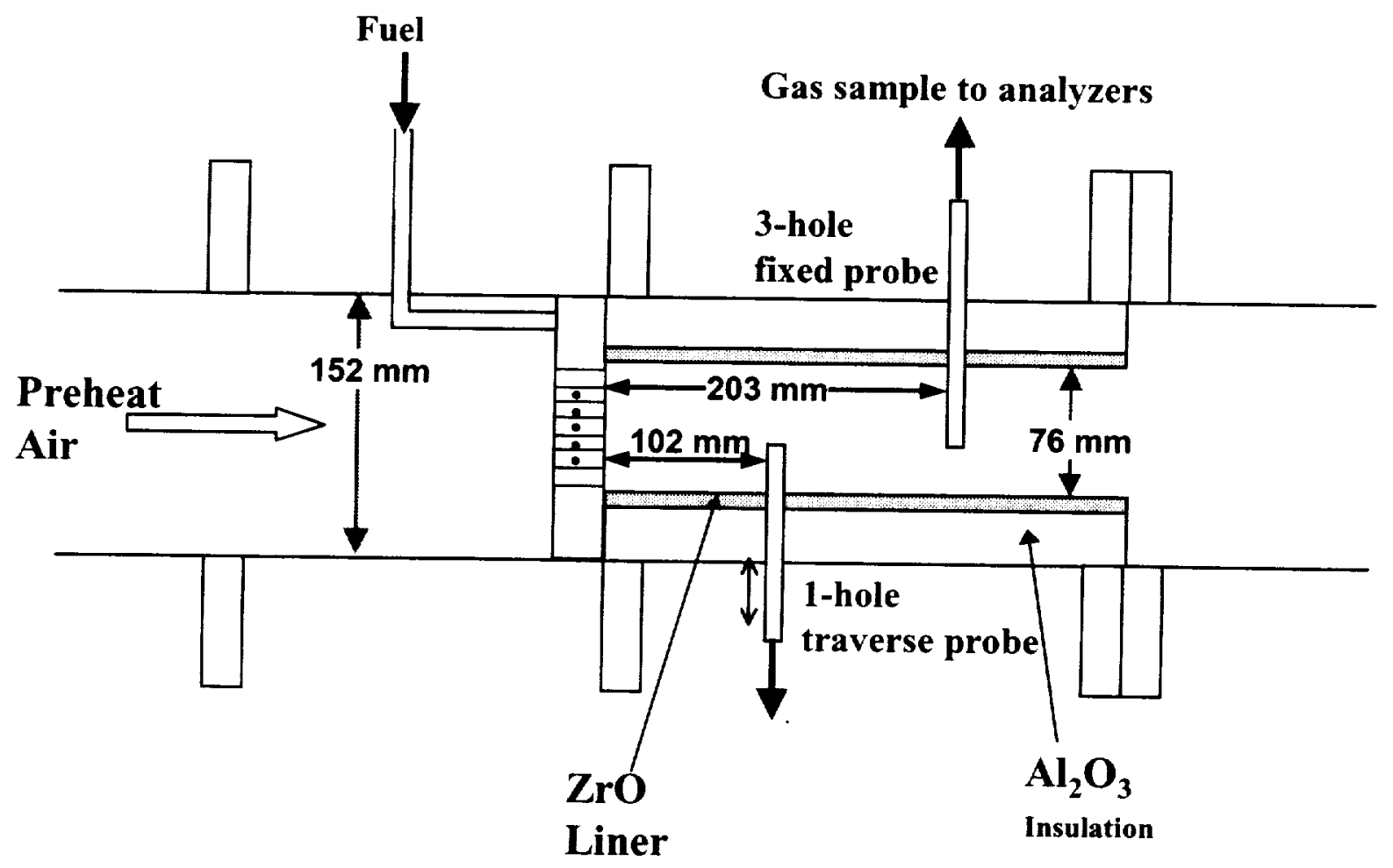

Figure 3. - Test facility schematic 


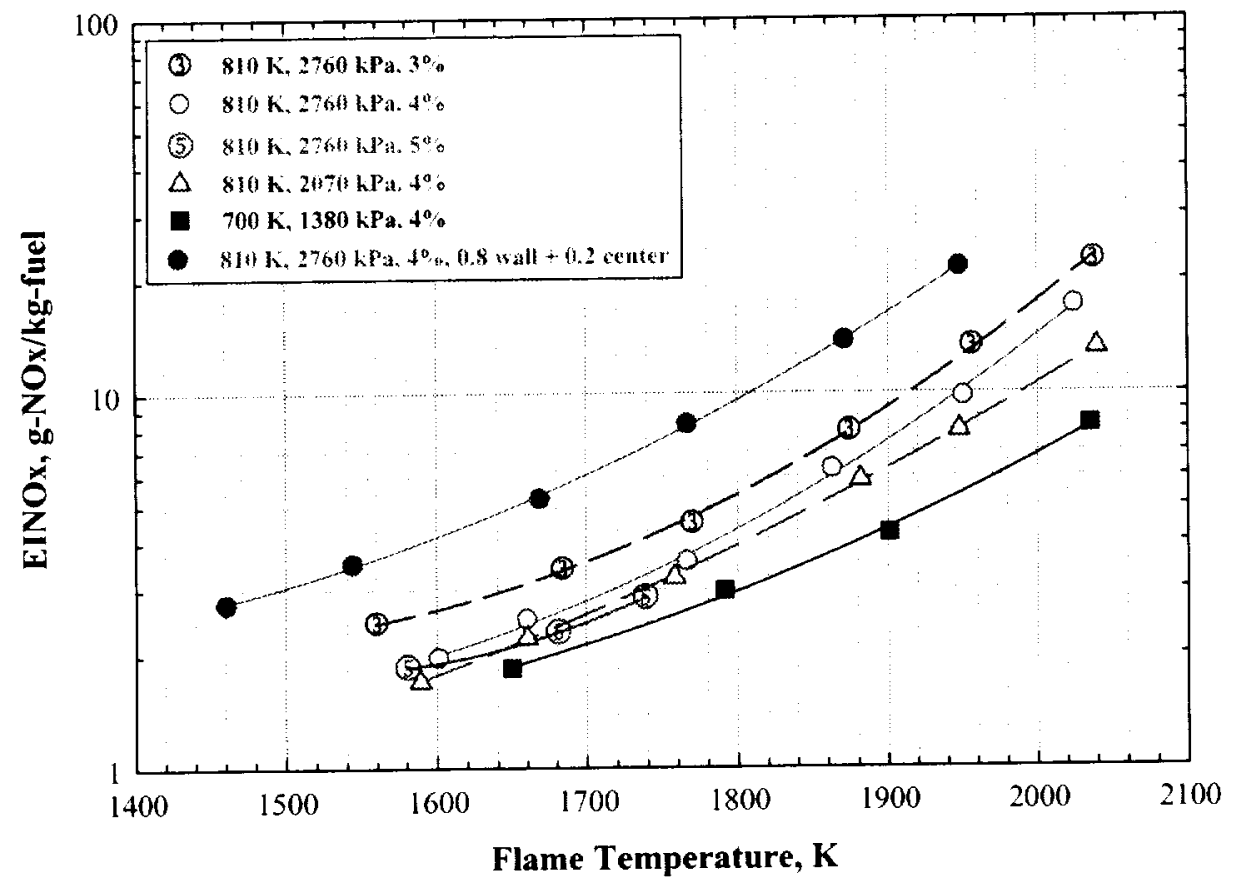

Figure 4a. - Configuration A, 6 injectors @ $\mathrm{FN}=0.17 \mathrm{~mm}^{2} /$ injector

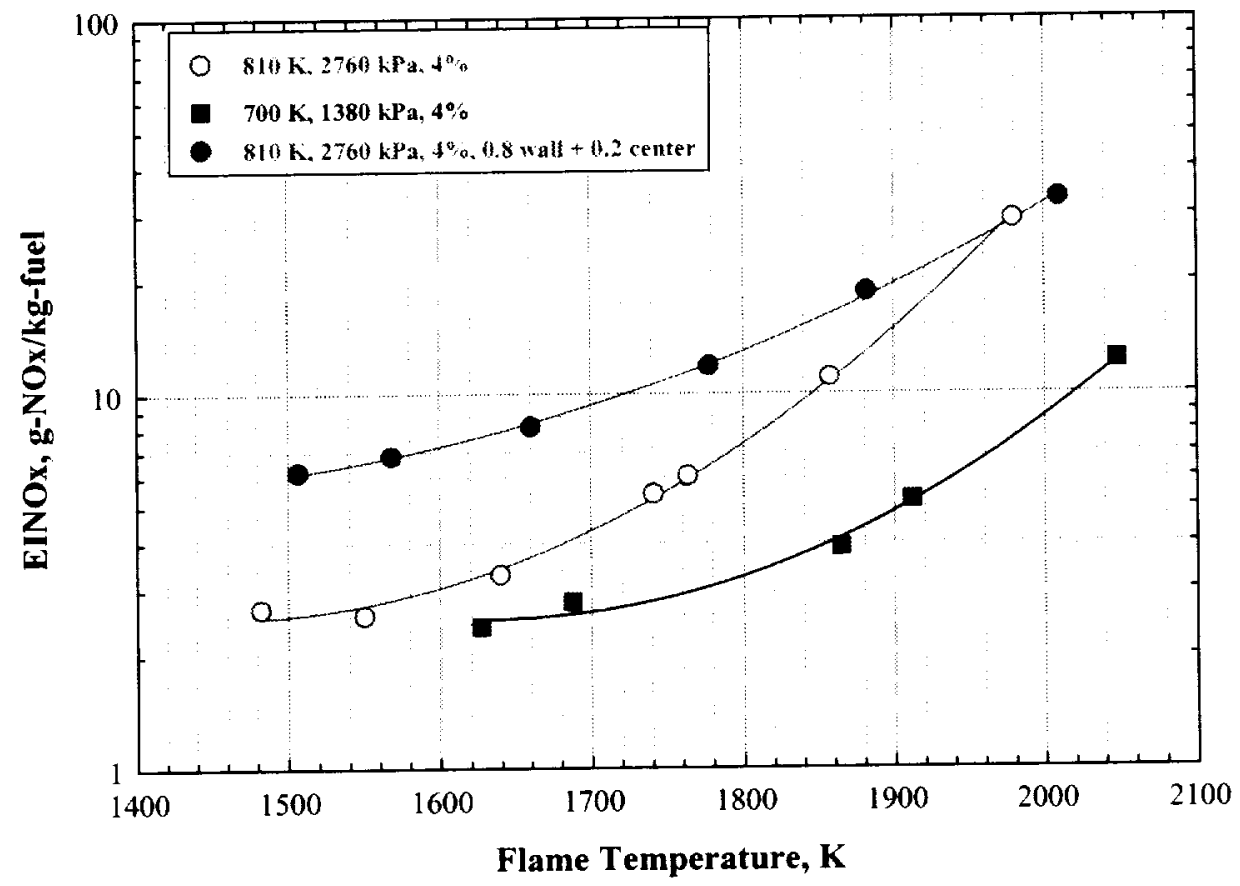

Figure 4b. - Configuration B, 4 injectors @ FN=0.20 $\mathrm{mm}^{2} /$ injector

Figure 4. - NOx emissions index as a function of adiabatic flame temperature for each configuration at various test conditions. 


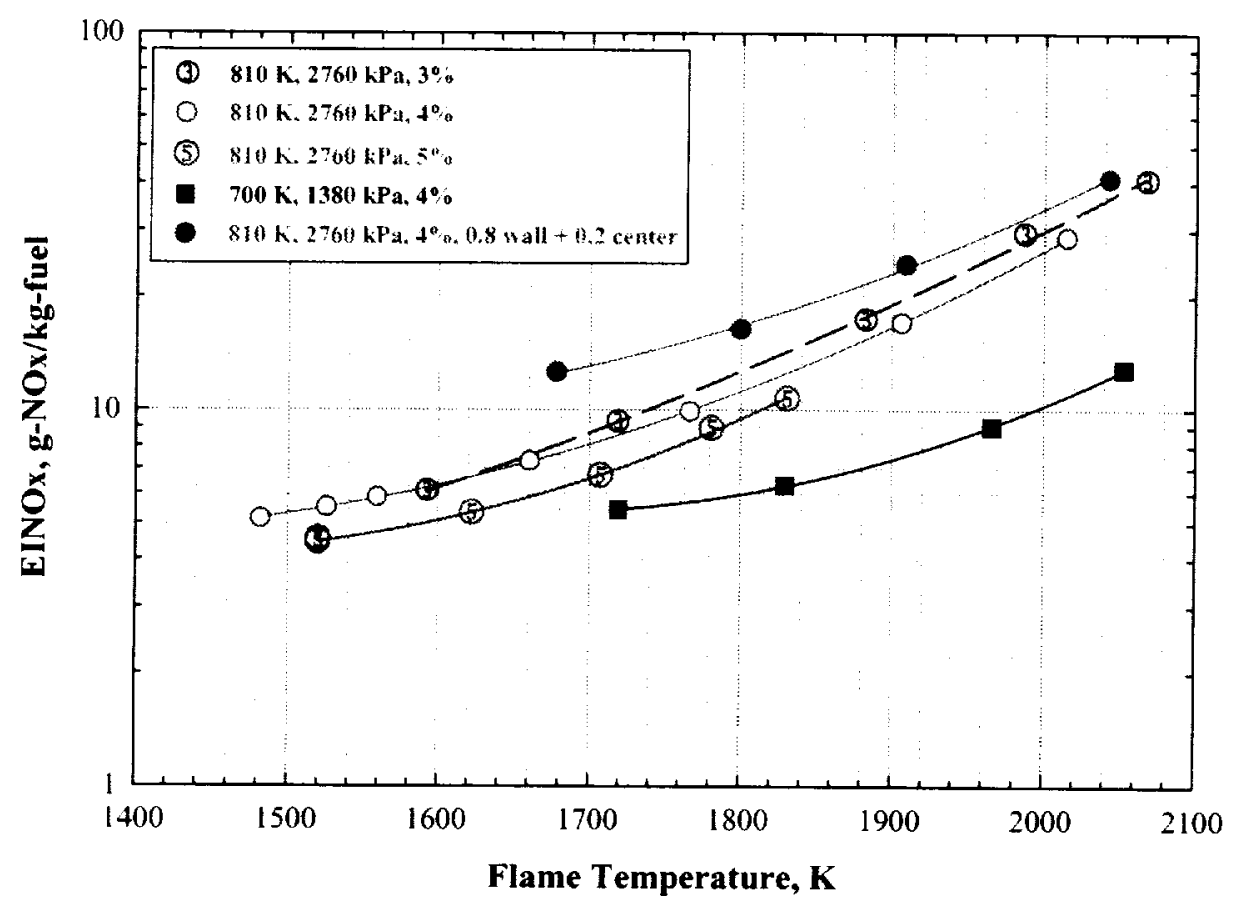

Figure 4c. - Configuration C, 4 injectors @ FN=0.24 $\mathrm{mm}^{2} /$ injector

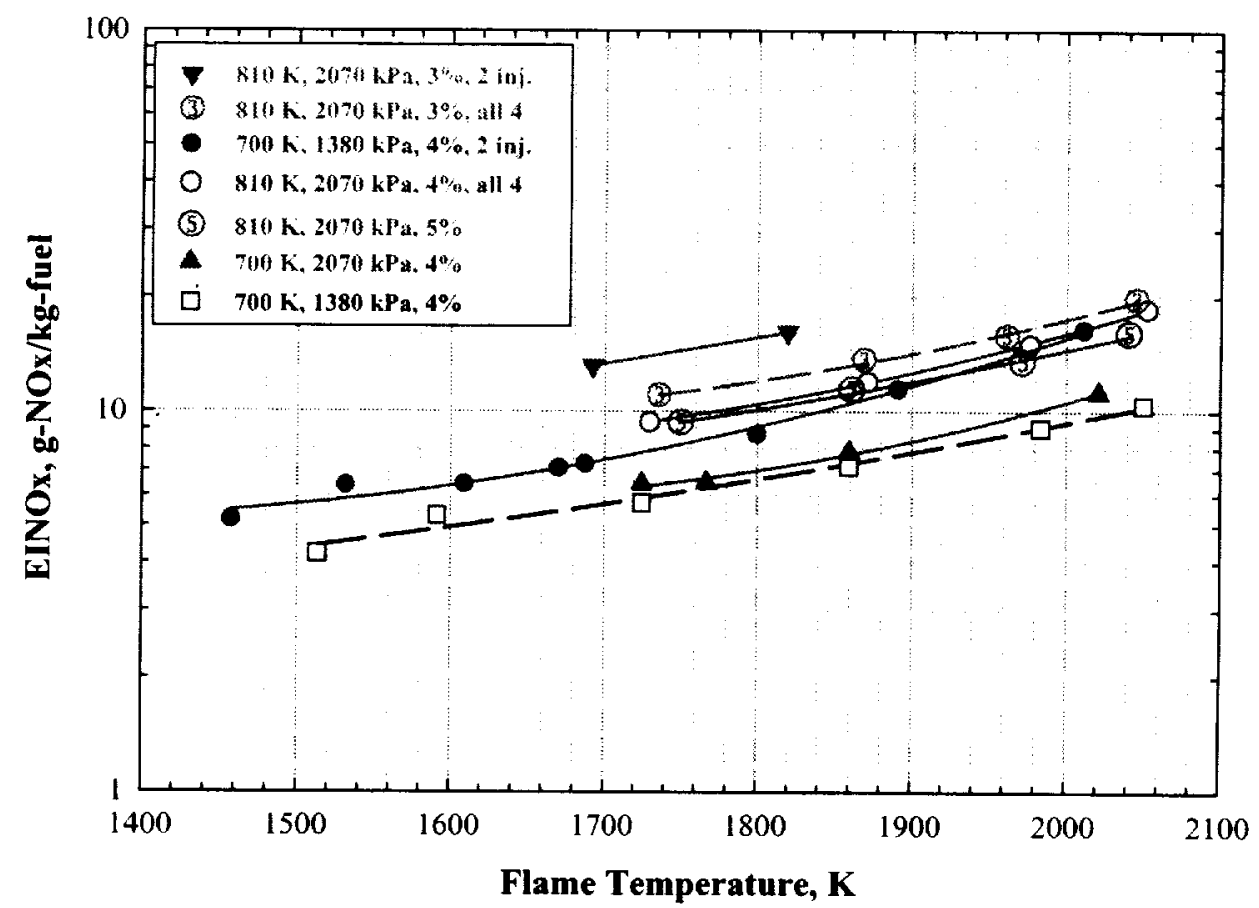

Figure 4d. - Configuration D, 4 injectors @ FN=0.47 mm , fan spray

Figure 4. - NOx emissions index as a function of adiabatic flame temperature for each configuration at various test conditions. 


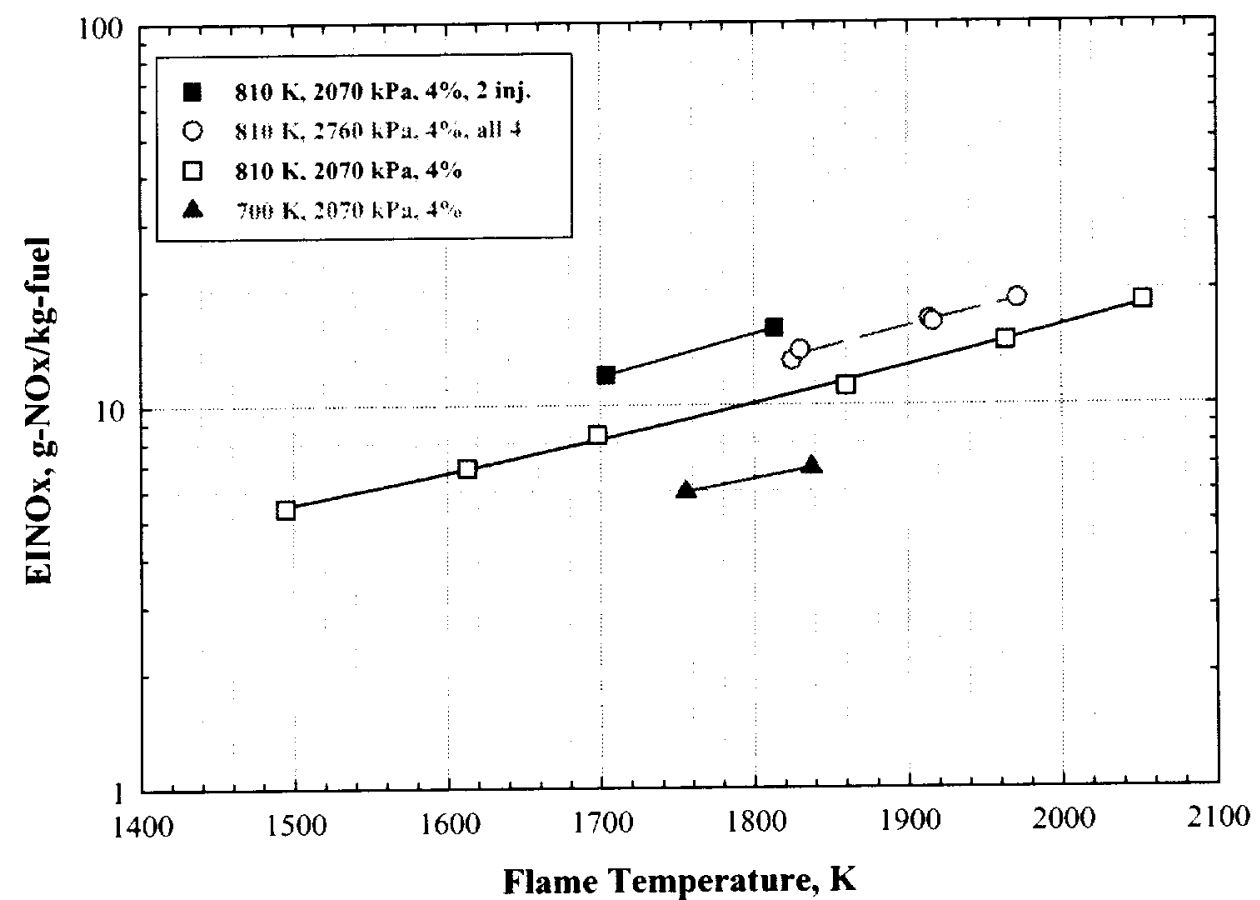

Figure 4e. - Configuration E, 4 injectors@ $\mathrm{FN}=0.48 \mathrm{~mm}^{2} /$ injector

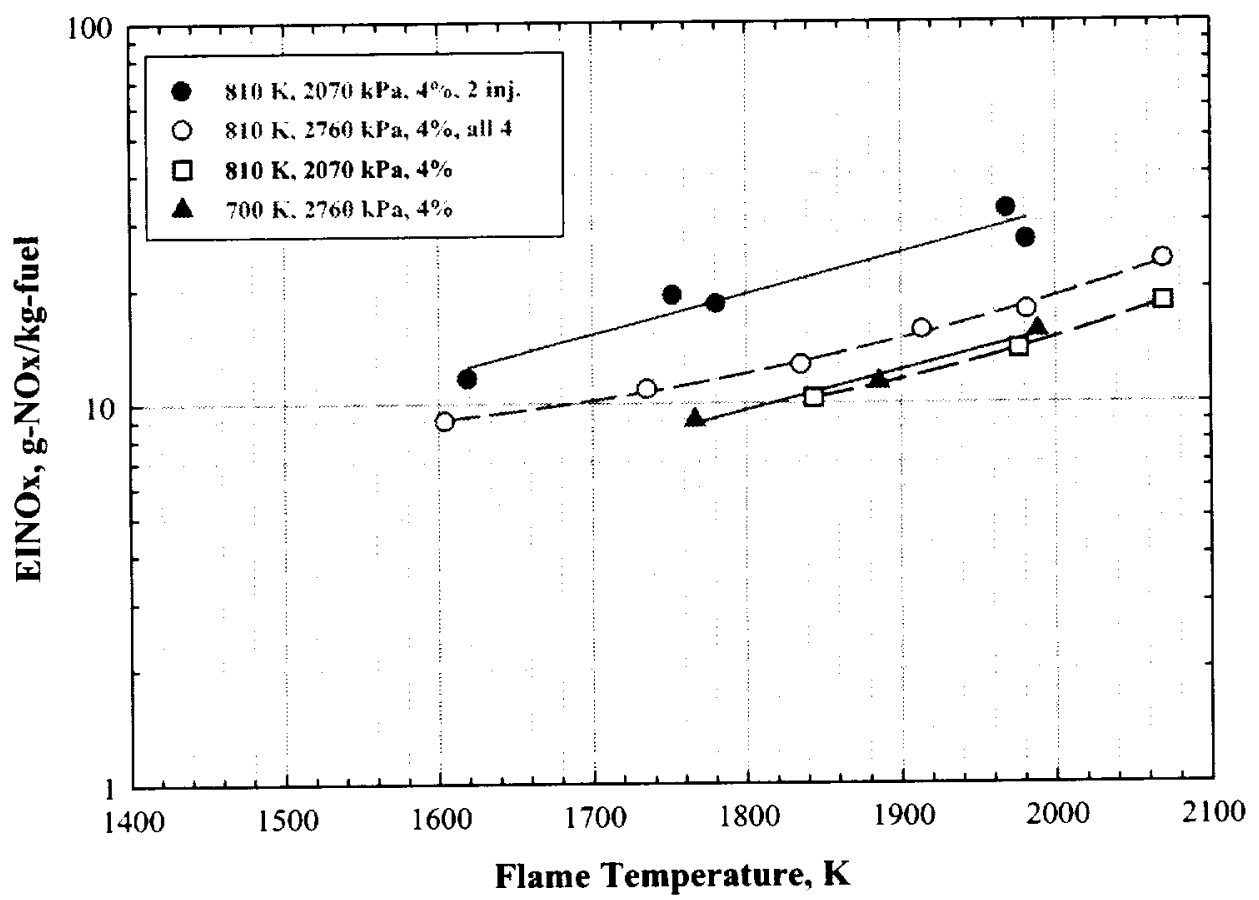

Figure 4f. - Configuration F, 4 injectors@ FN=0.67 mm² / injector

Figure 4. - NOx emissions index as a function of adiabatic flame temperature for each configuration at various test conditions. 


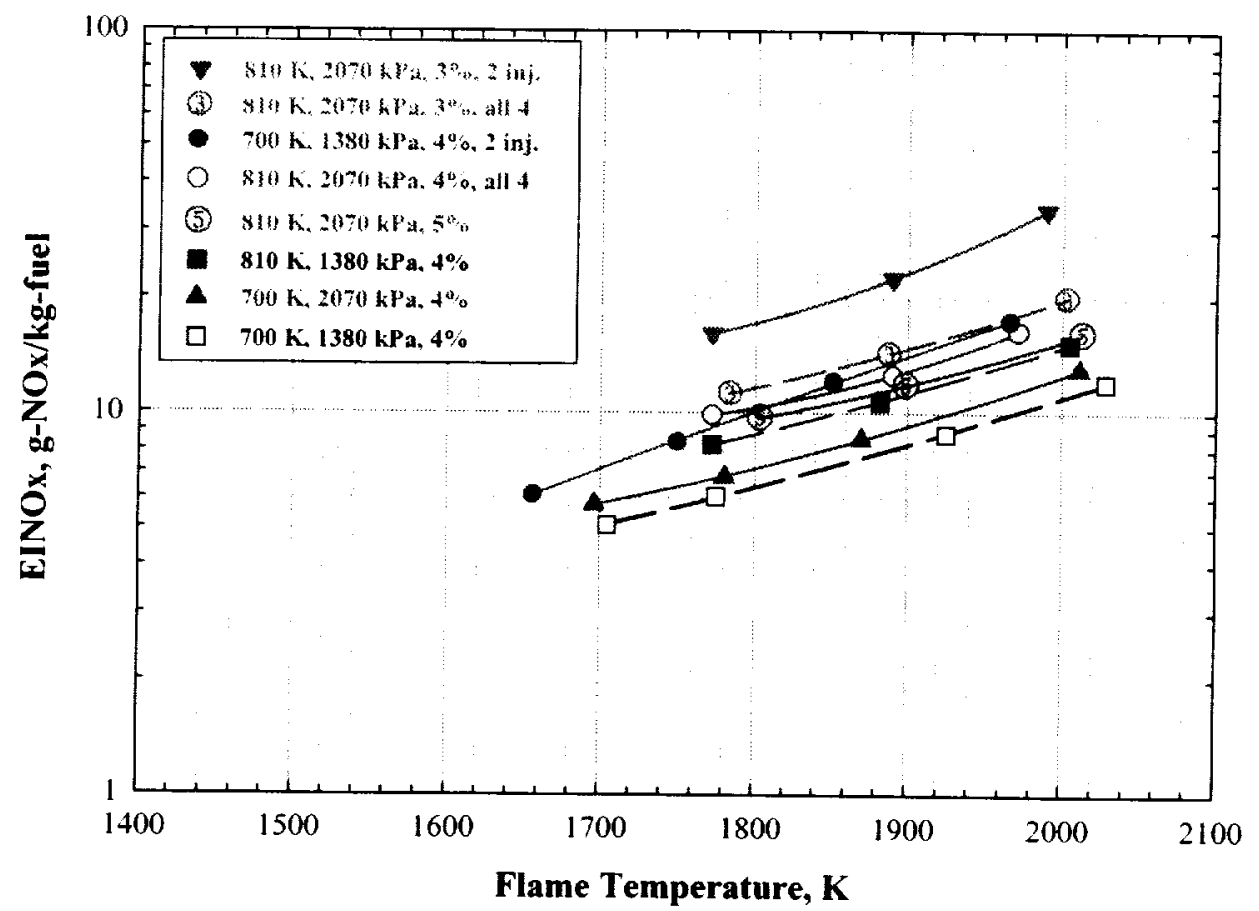

Figure 4g. - Configuration G, 4 injectors @ FN=0.78 $\mathrm{mm}^{2} /$ injector

Figure 4. - NOx emissions index as a function of adiabatic flame temperature for each configuration at various test conditions. 


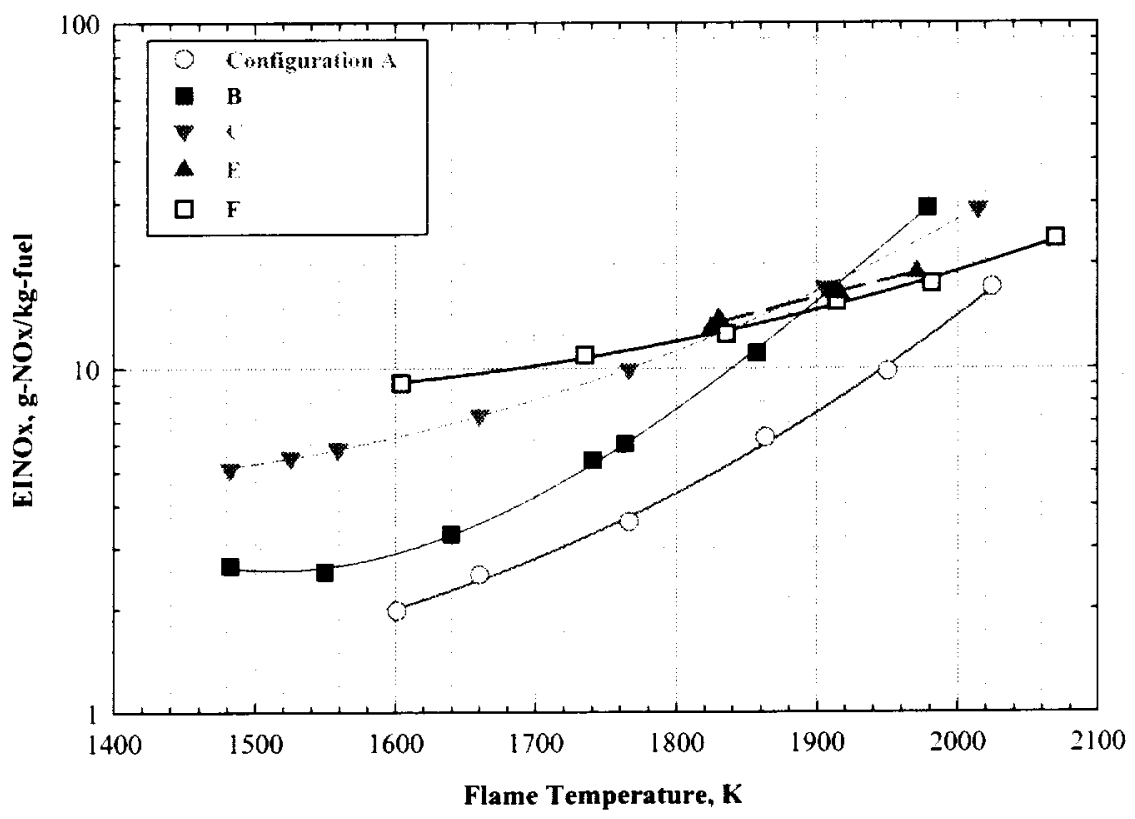

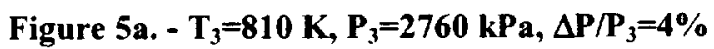

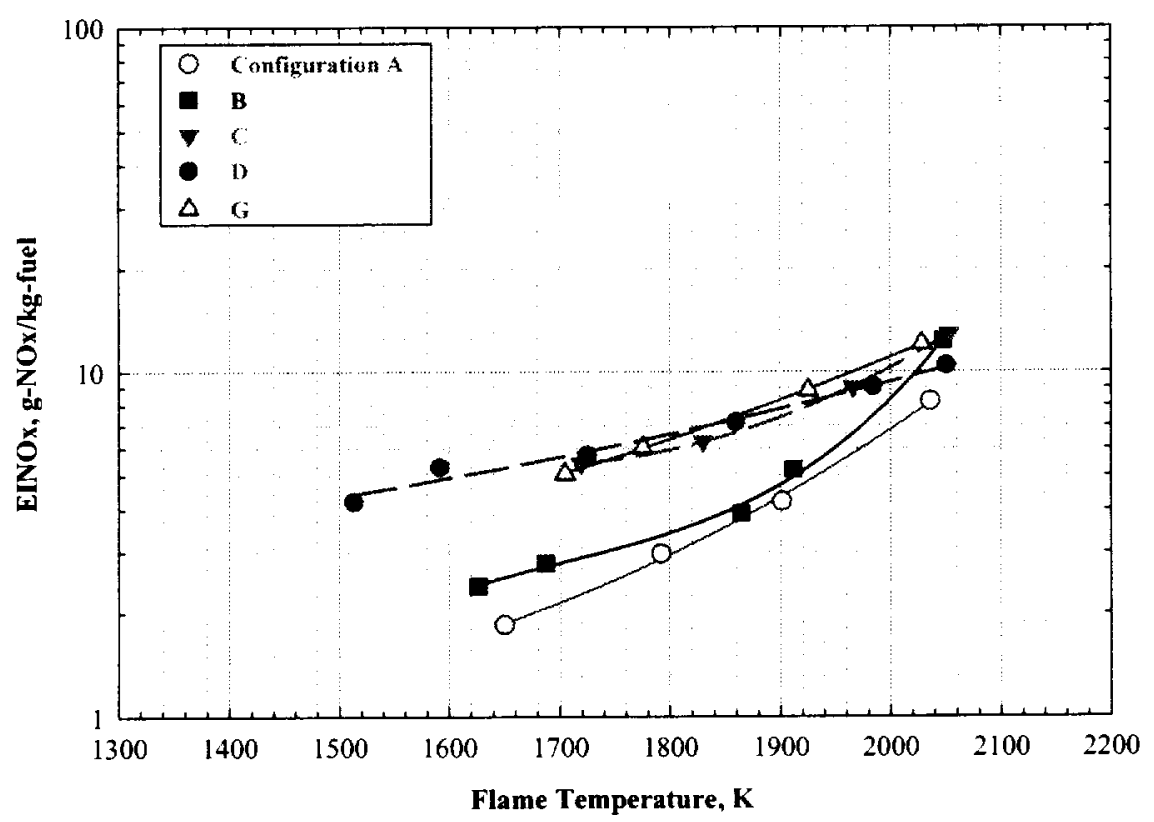

Figure 5b. - $T_{3}=700 \mathrm{~K}, \mathrm{P}_{3}=1380 \mathrm{kPa}, \Delta \mathrm{P} / \mathrm{P}_{3}=4 \%$

Figure 5. - Comparison of NOx emissions with configuration 


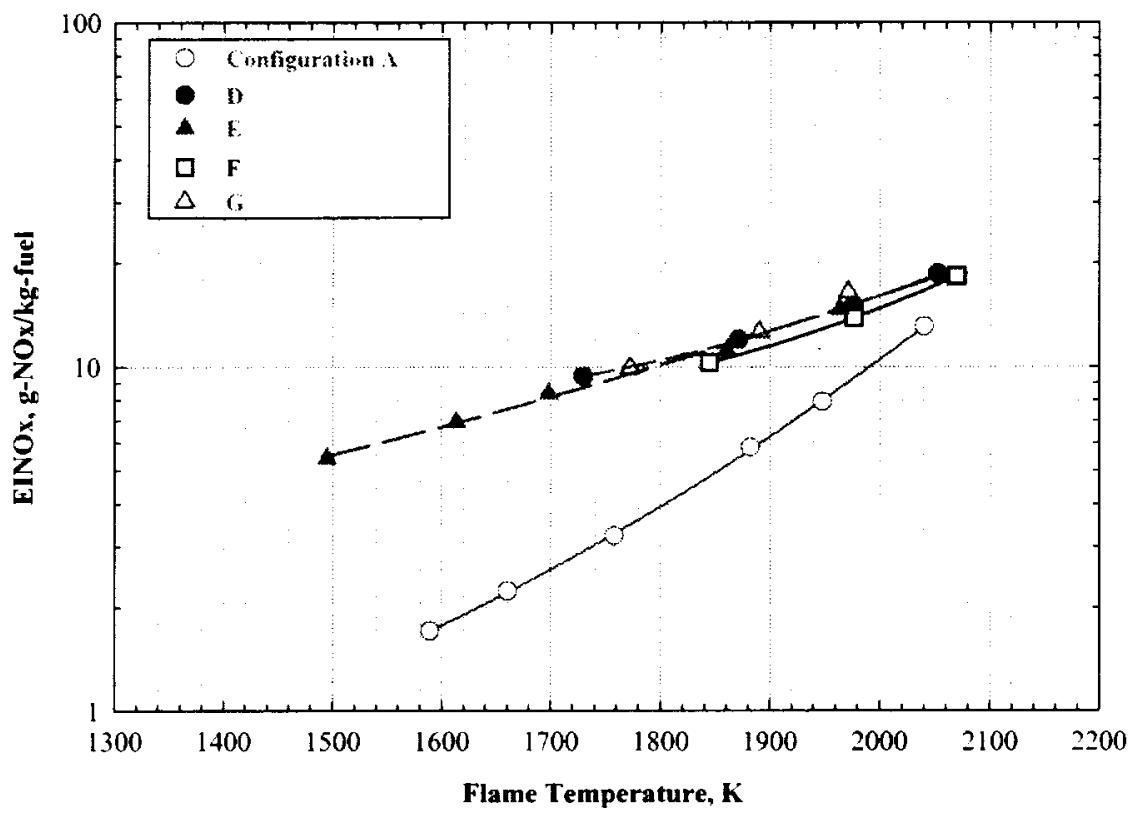

Figure 5c. $-T_{3}=810 \mathrm{~K}, P_{3}=2070 \mathrm{kPa}, \Delta P / P_{3}=4 \%$

Figure 5. - Comparison of NOx emissions with configuration 


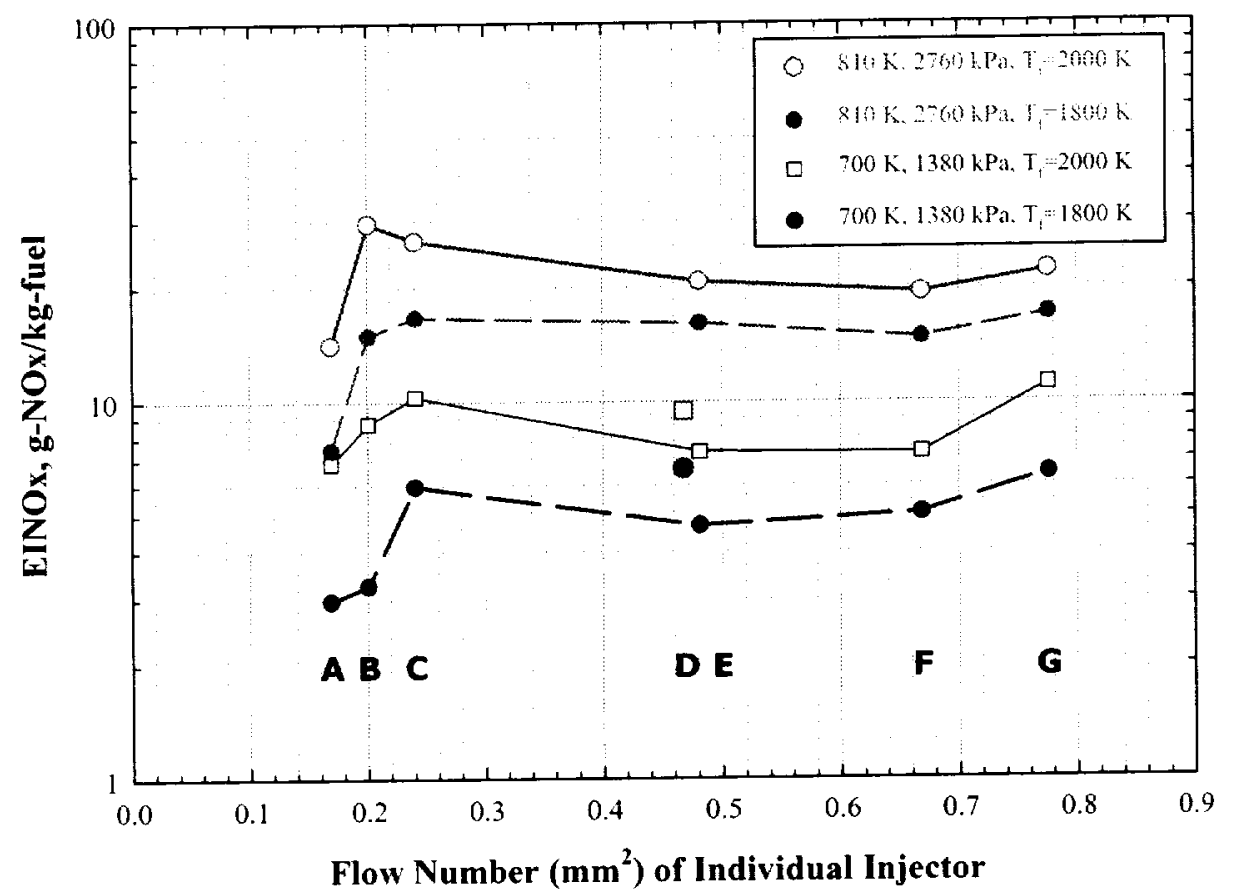

Figure 6. - Comparisons of NOx emissions as a function of fuel injector flow number at $\Delta \mathrm{P} / \mathrm{P}_{3}=4 \%$ 


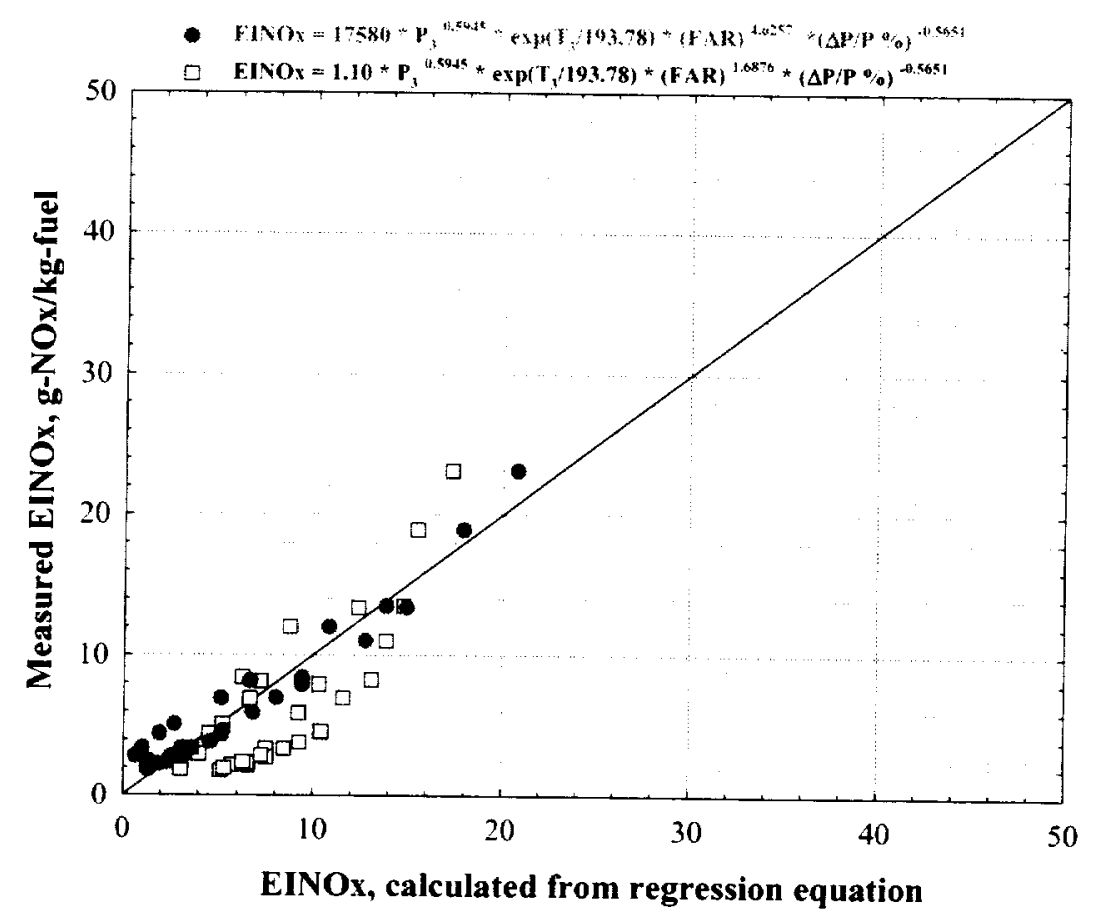

Figure 7a. - Configuration A

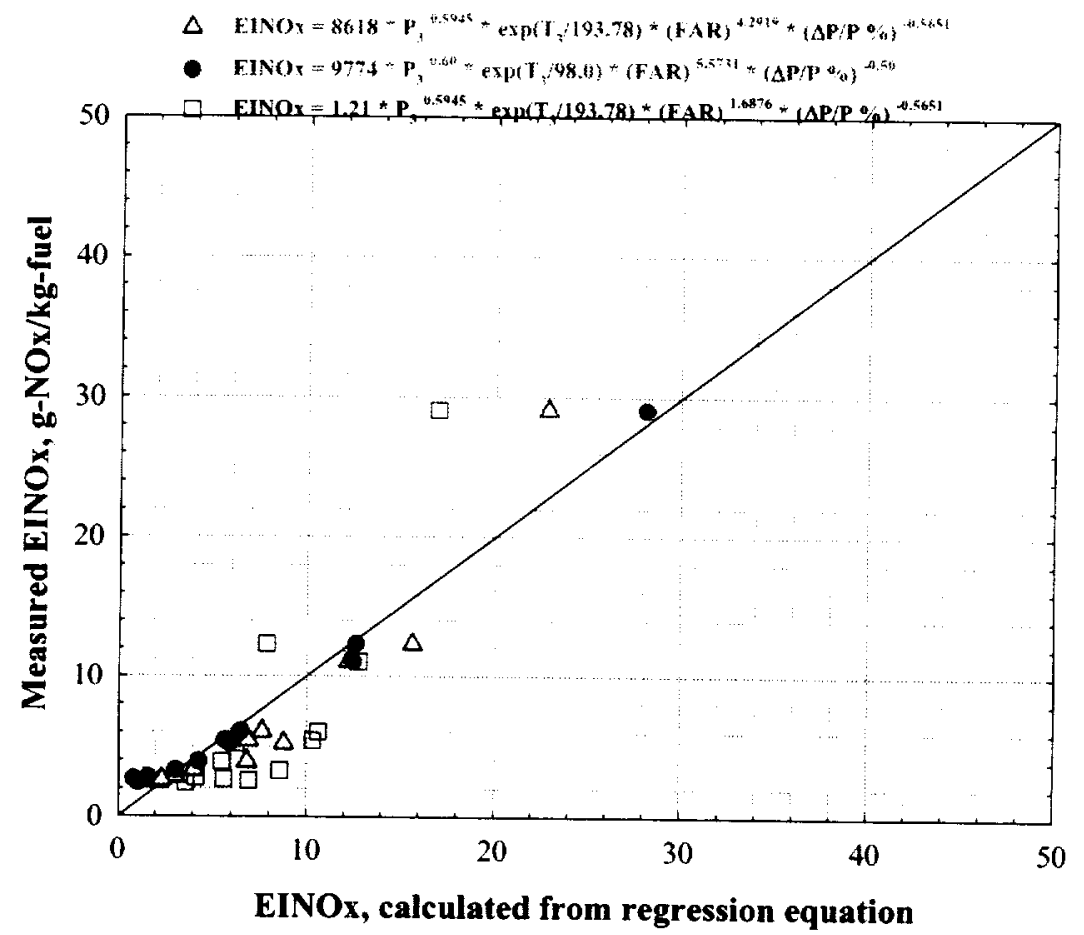

Figure 7b. - Configuration B

Figure 7. - NOx emissions correlated with inlet conditions 


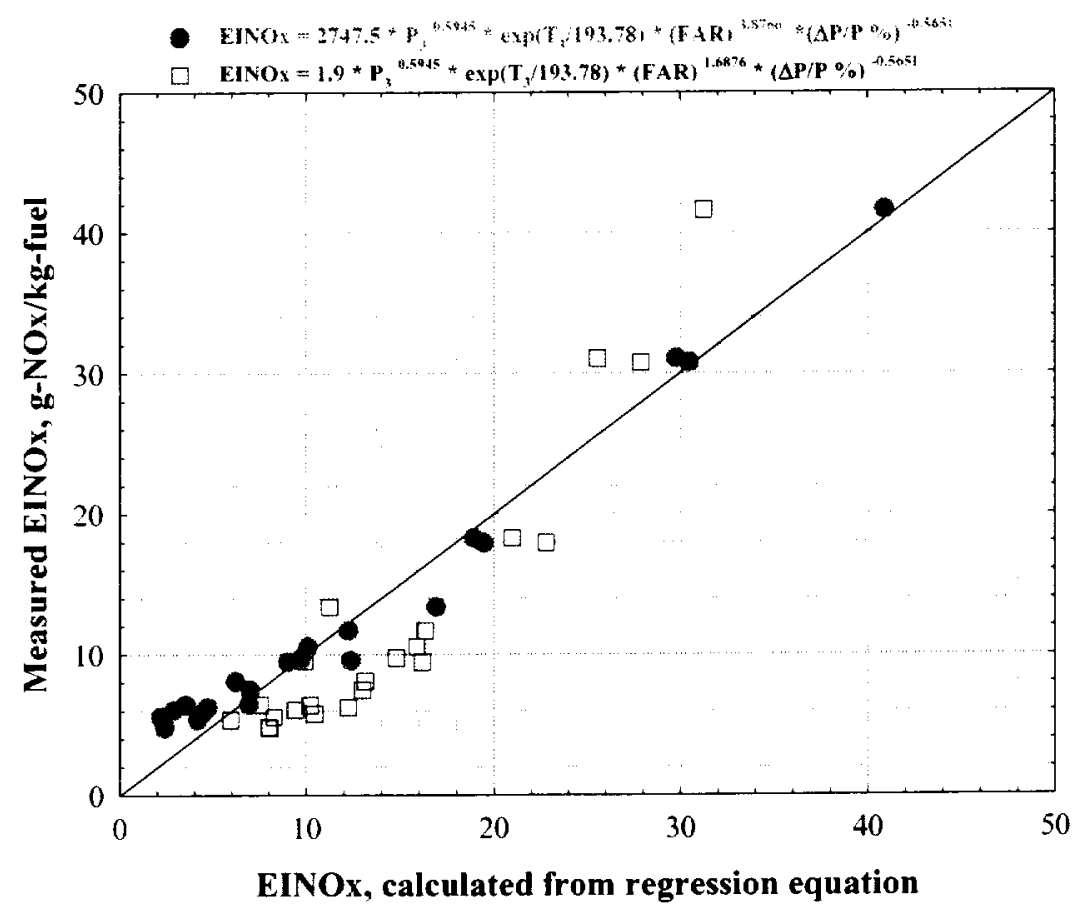

Figure 7c. - Configuration $\mathrm{C}$

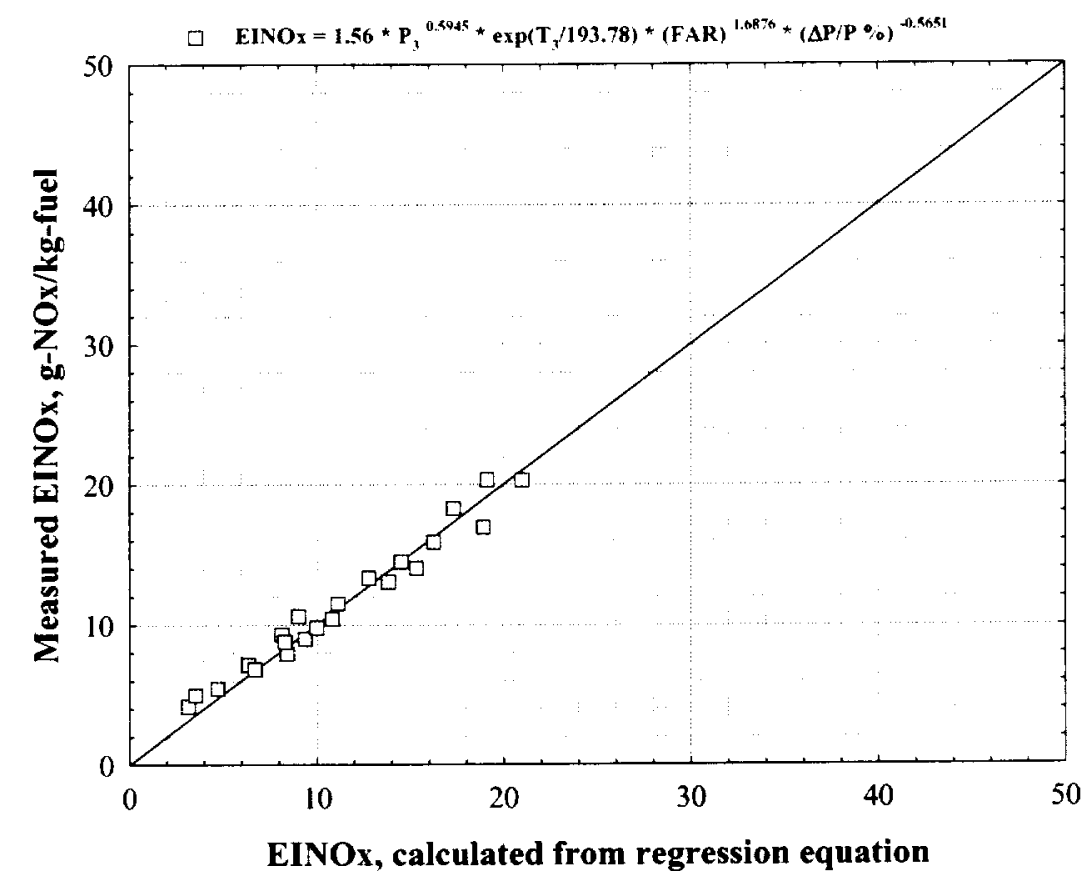

Figure 7d. - Configuration D

Figure 7. - NOx emissions correlated with inlet conditions 


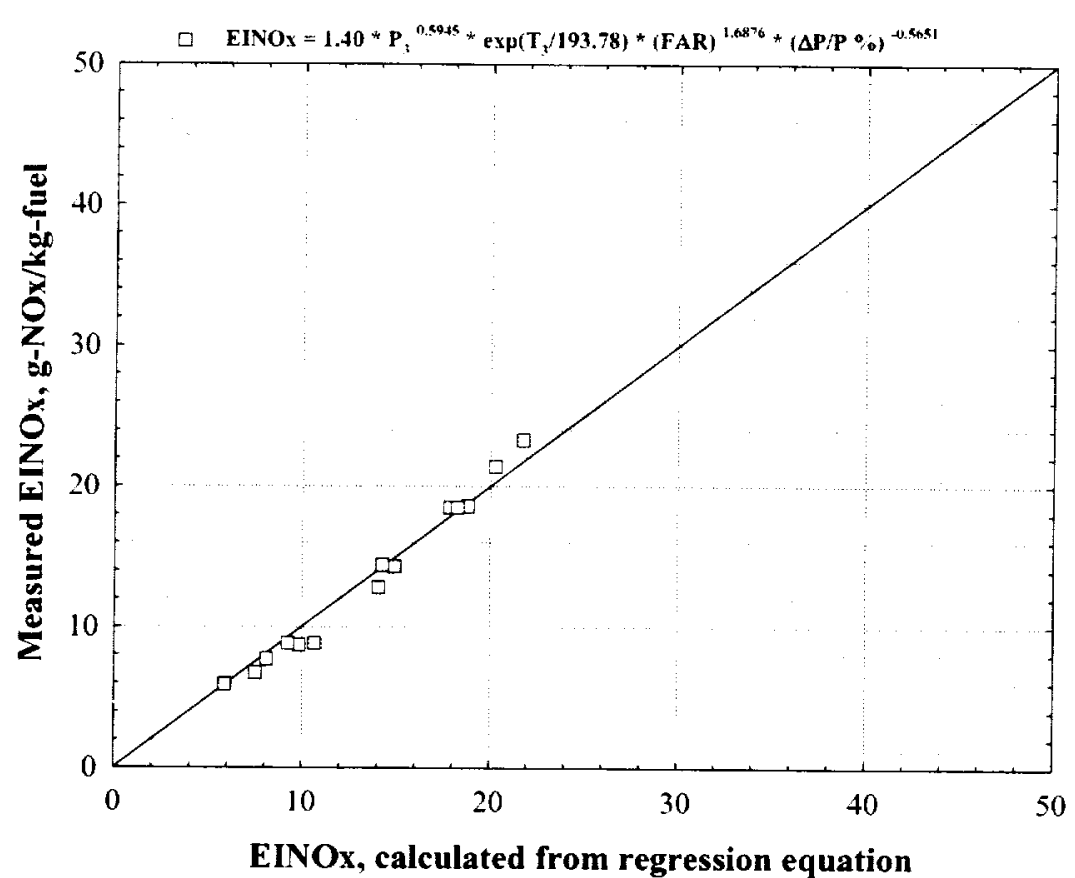

Figure 7e. - Configuration $E$

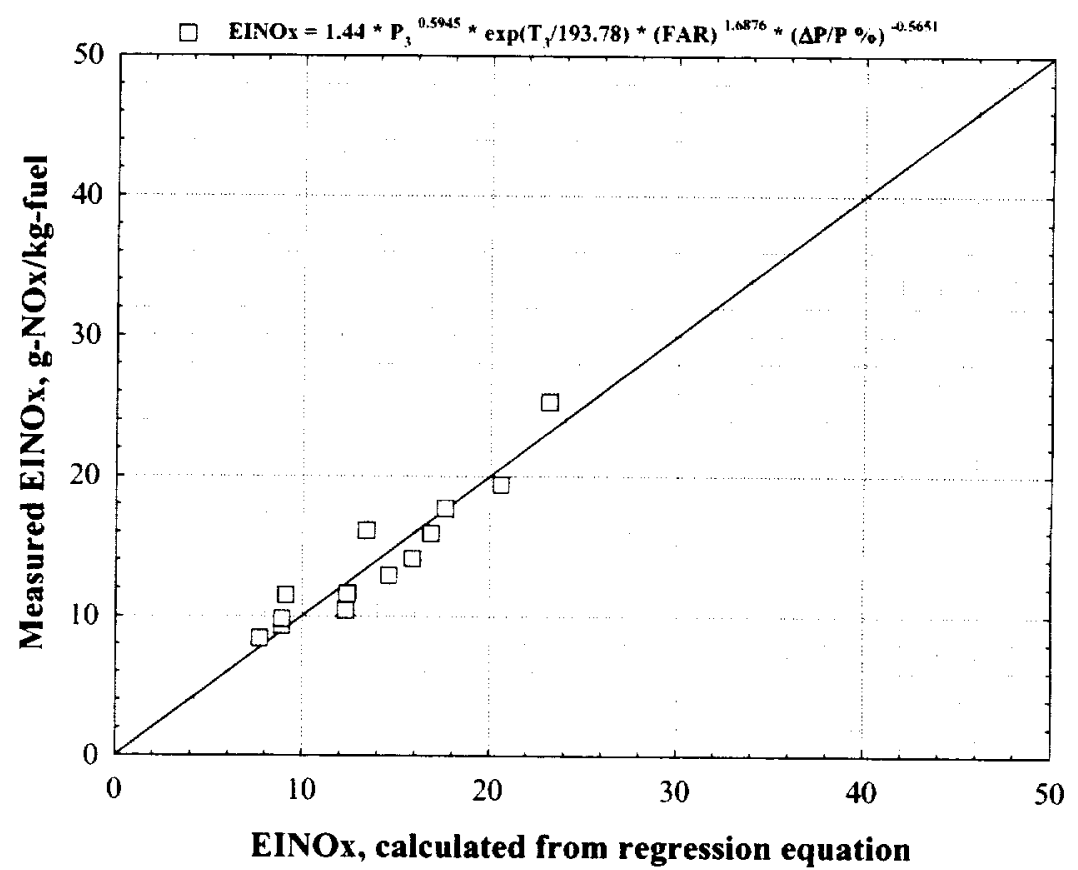

Figure 7f. - Configuration $F$

Figure 7. - NOx emissions correlated with inlet conditions 


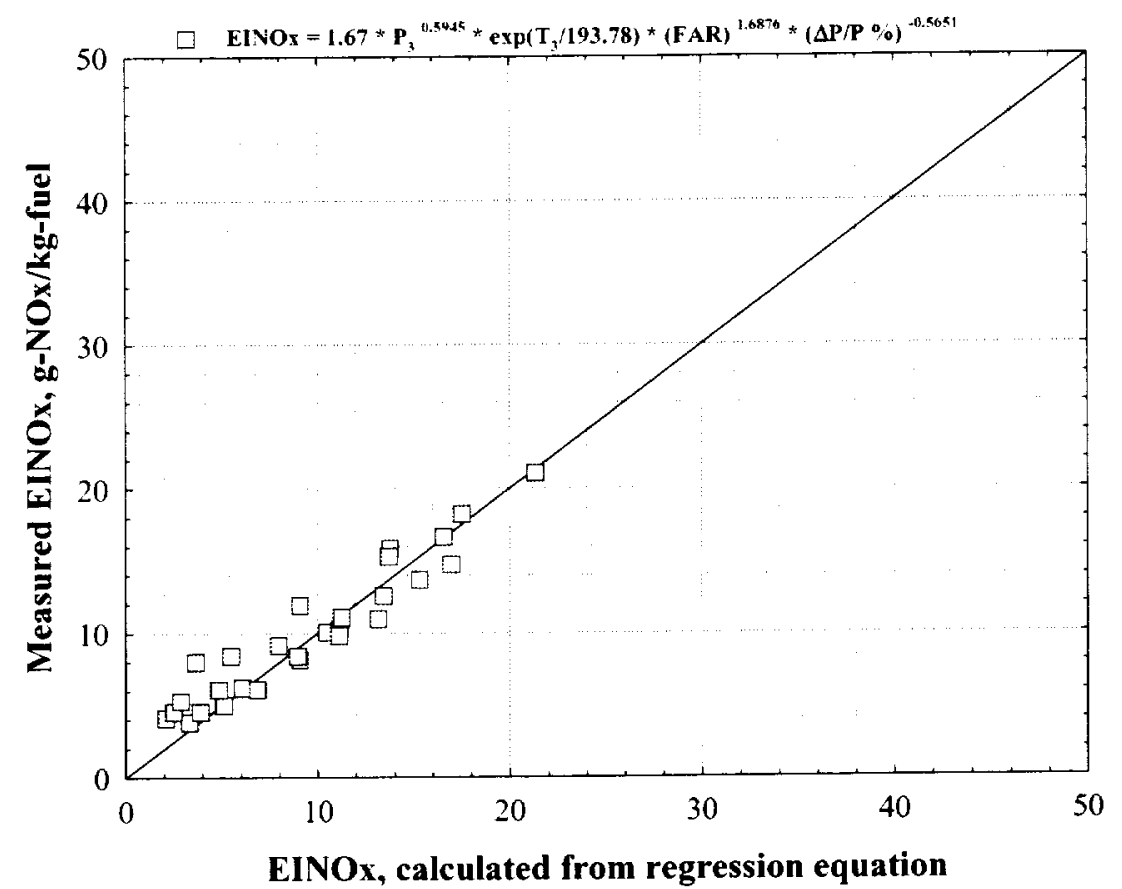

Figure 7g. - Configuration $\mathrm{G}$

Figure 7. - NOx emissions correlated with inlet conditions 


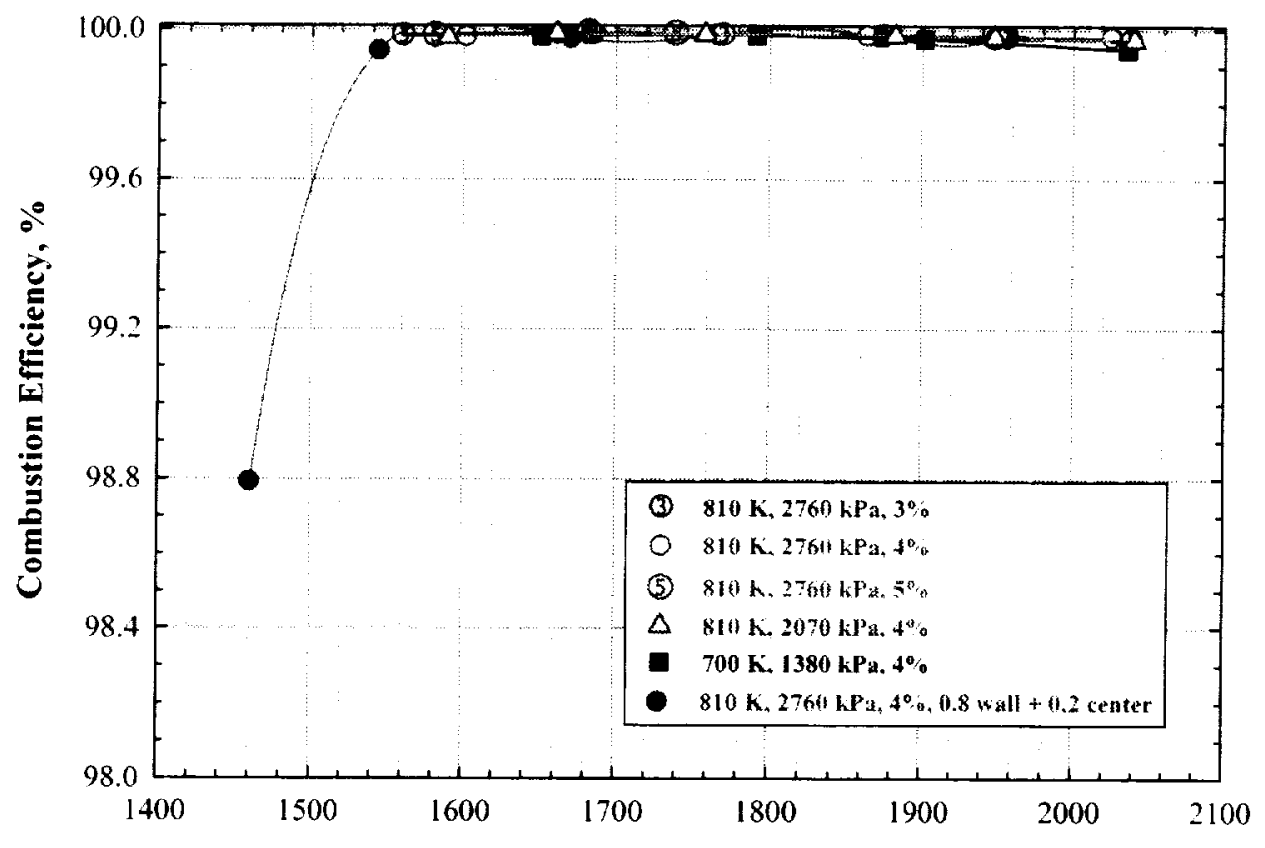

Flame Temperature, $K$

Figure 8a. - Configuration A

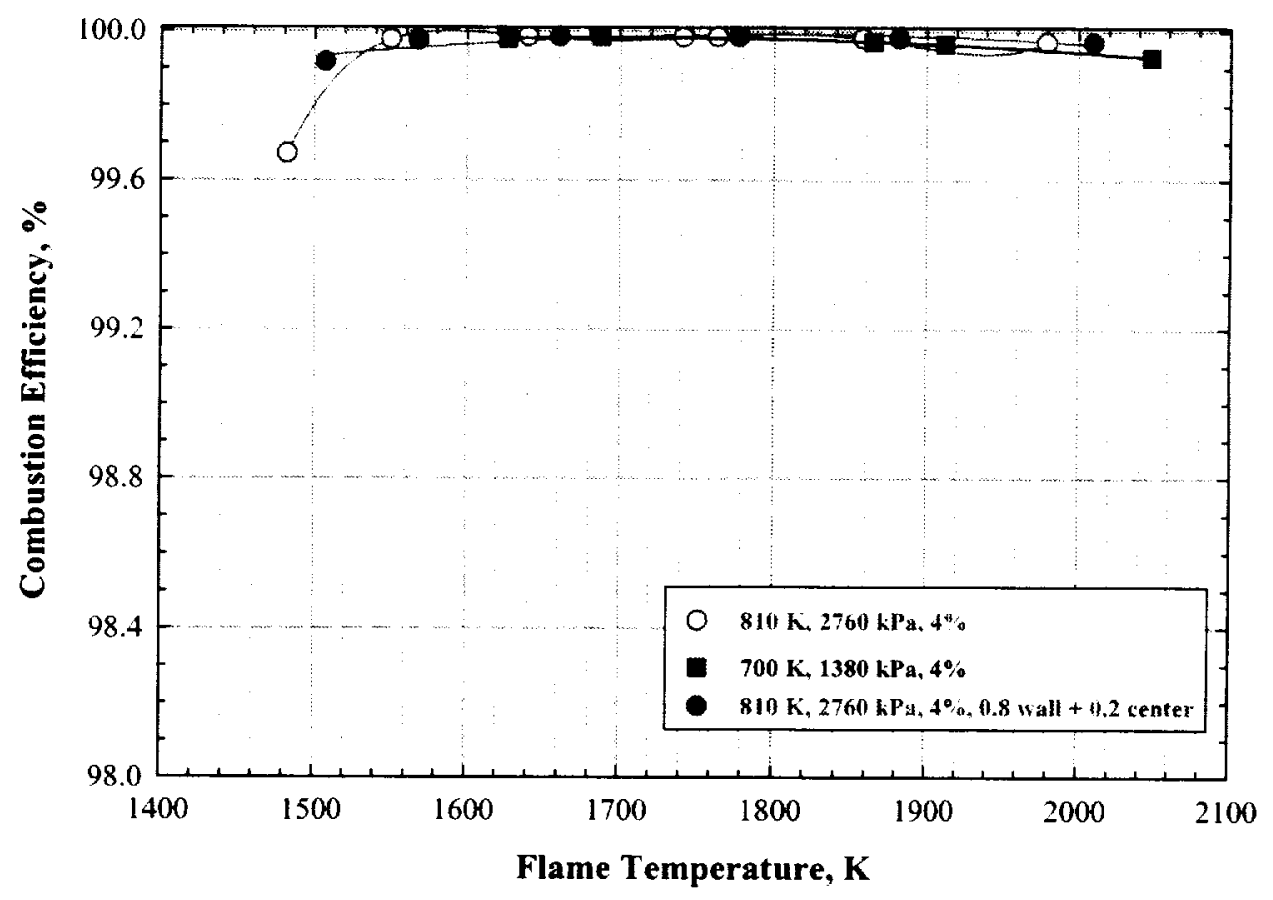

Figure 8b. - Configuration B

Figure 8. - Combustion efficiency as a function of flame temperature for each configuration 


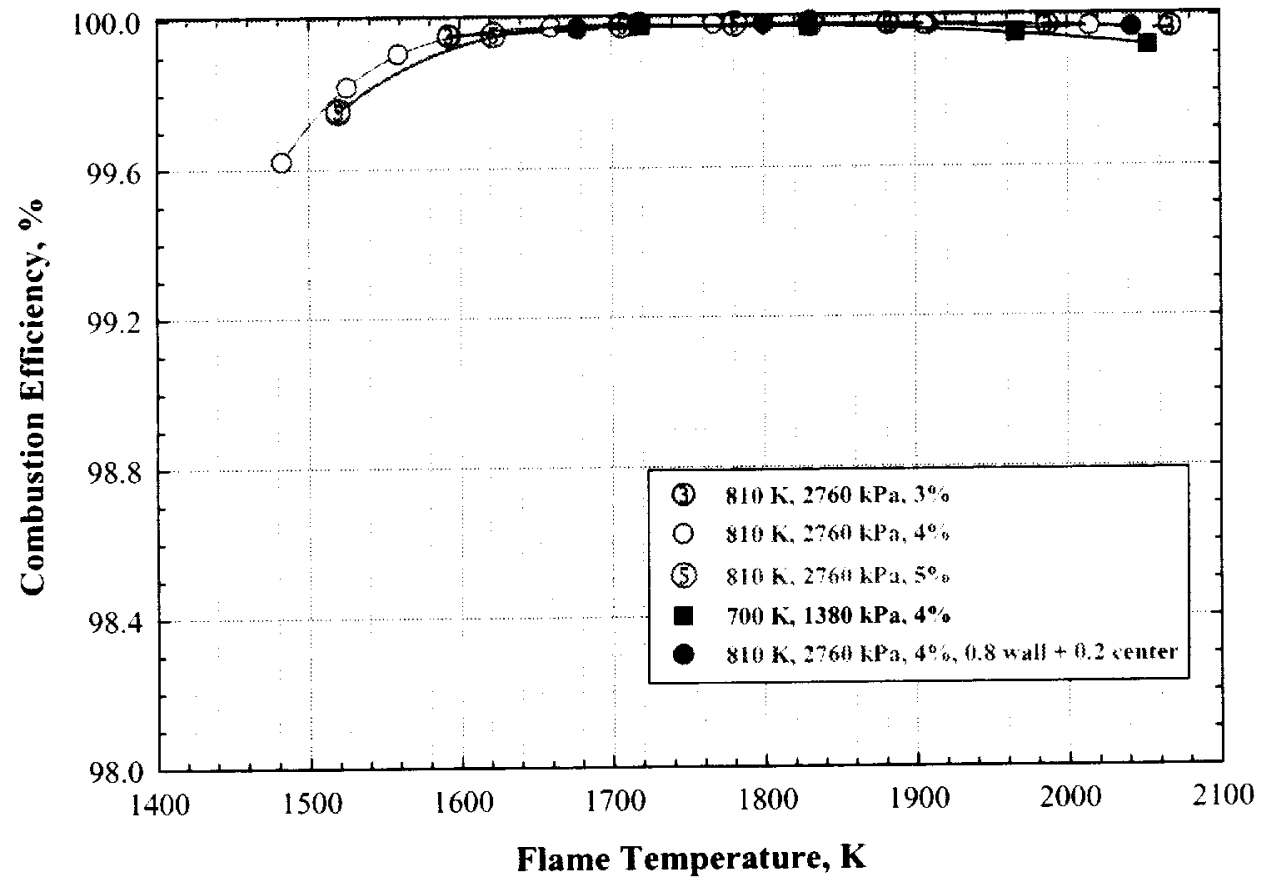

Figure 8c. - Configuration C

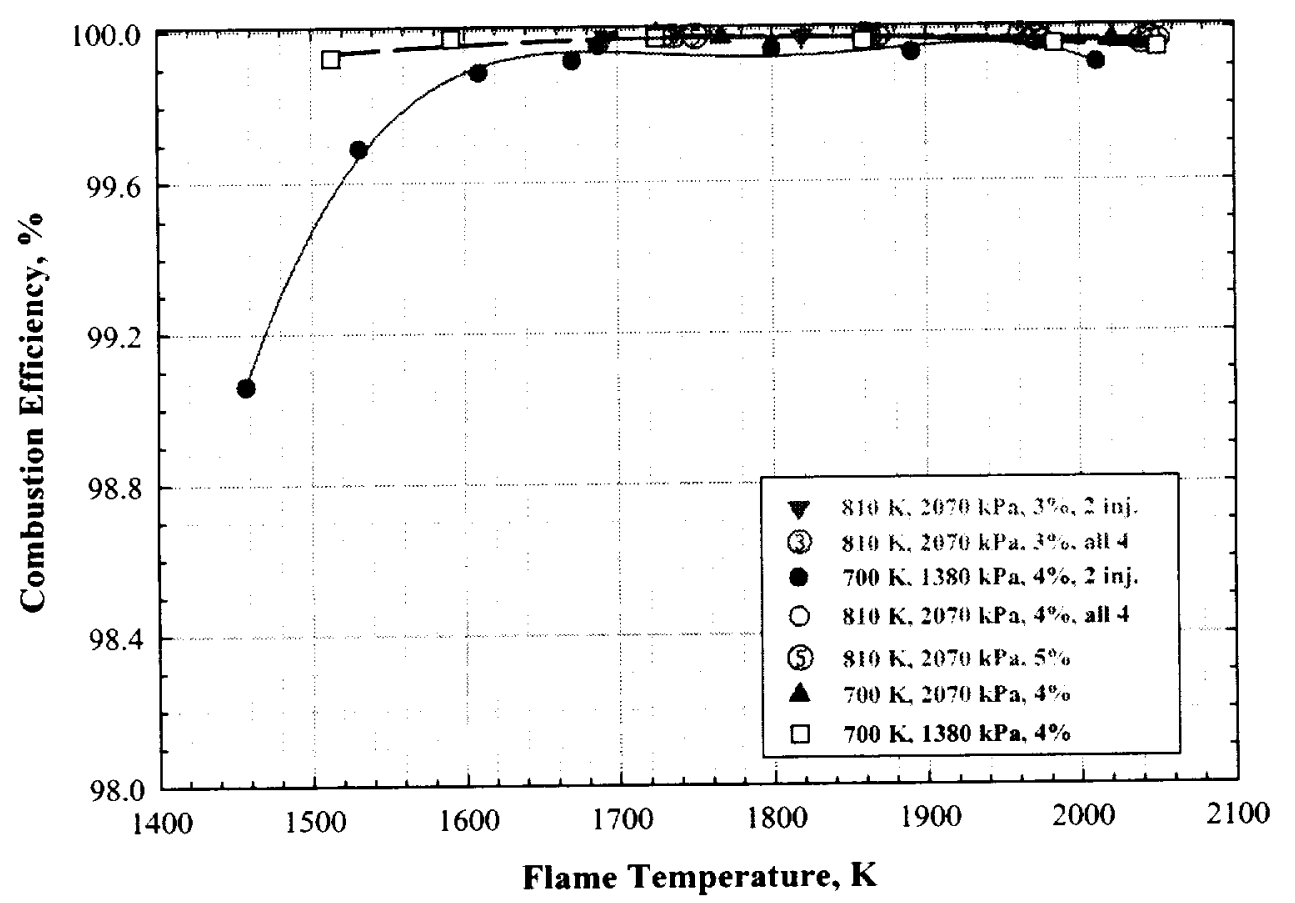

Figure 8d. - Configuration D

Figure 8. - Combustion efficiency as a function of name temperature for each configuration 


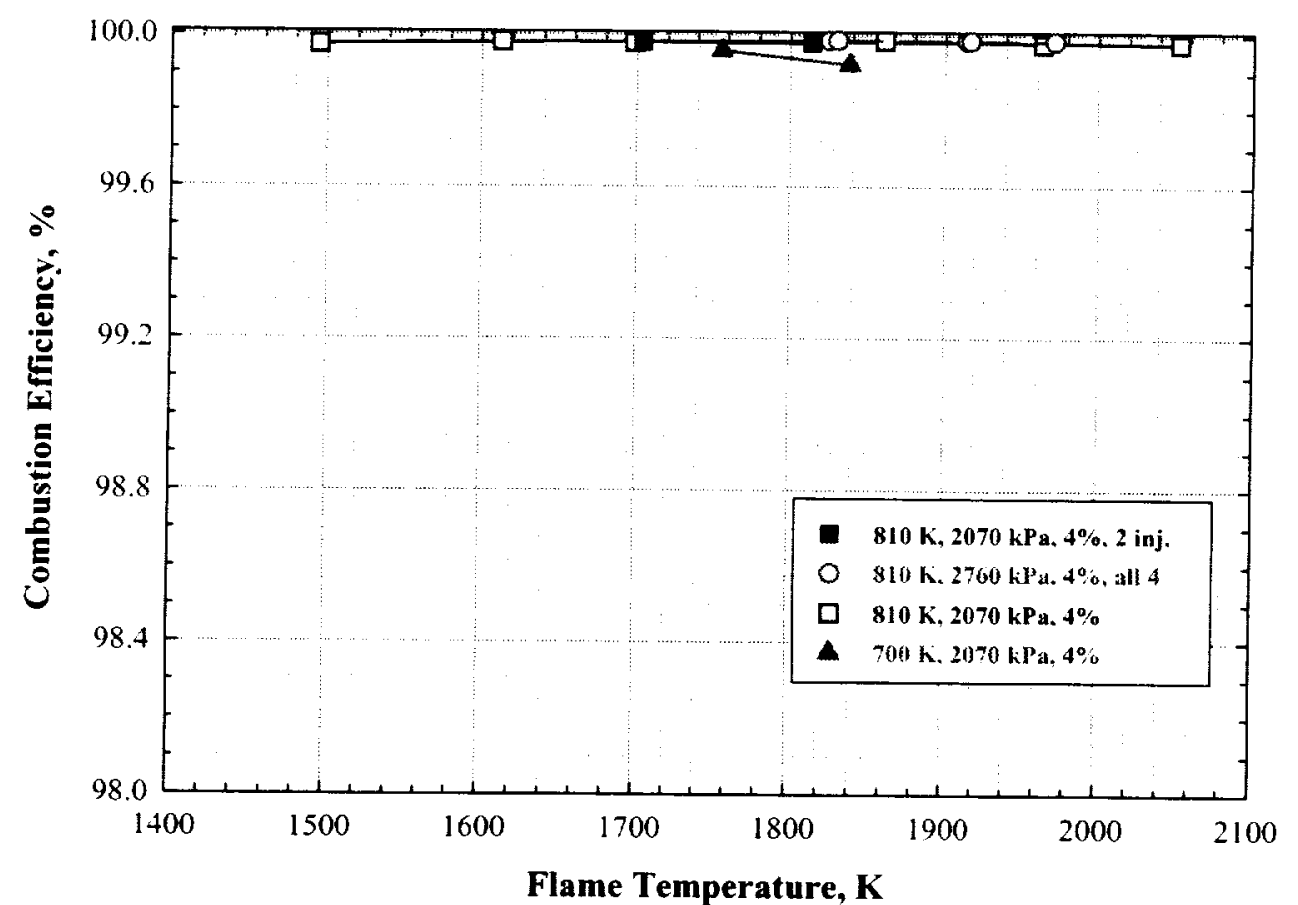

Figure 8e. - Configuration E

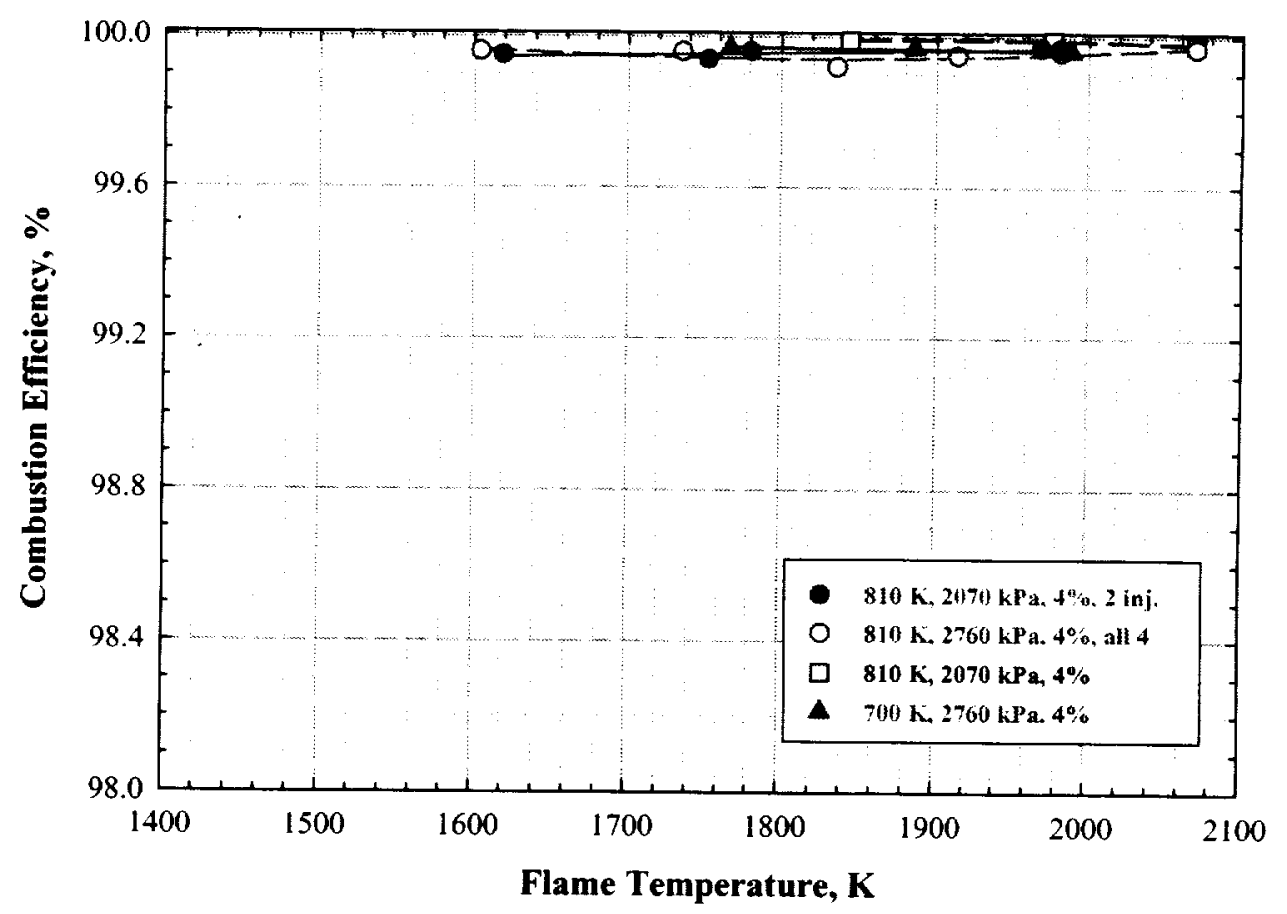

Figure 8f. - Configuration $F$

Figure 8. - Combustion efficiency as a function of flame temperature for each configuration 


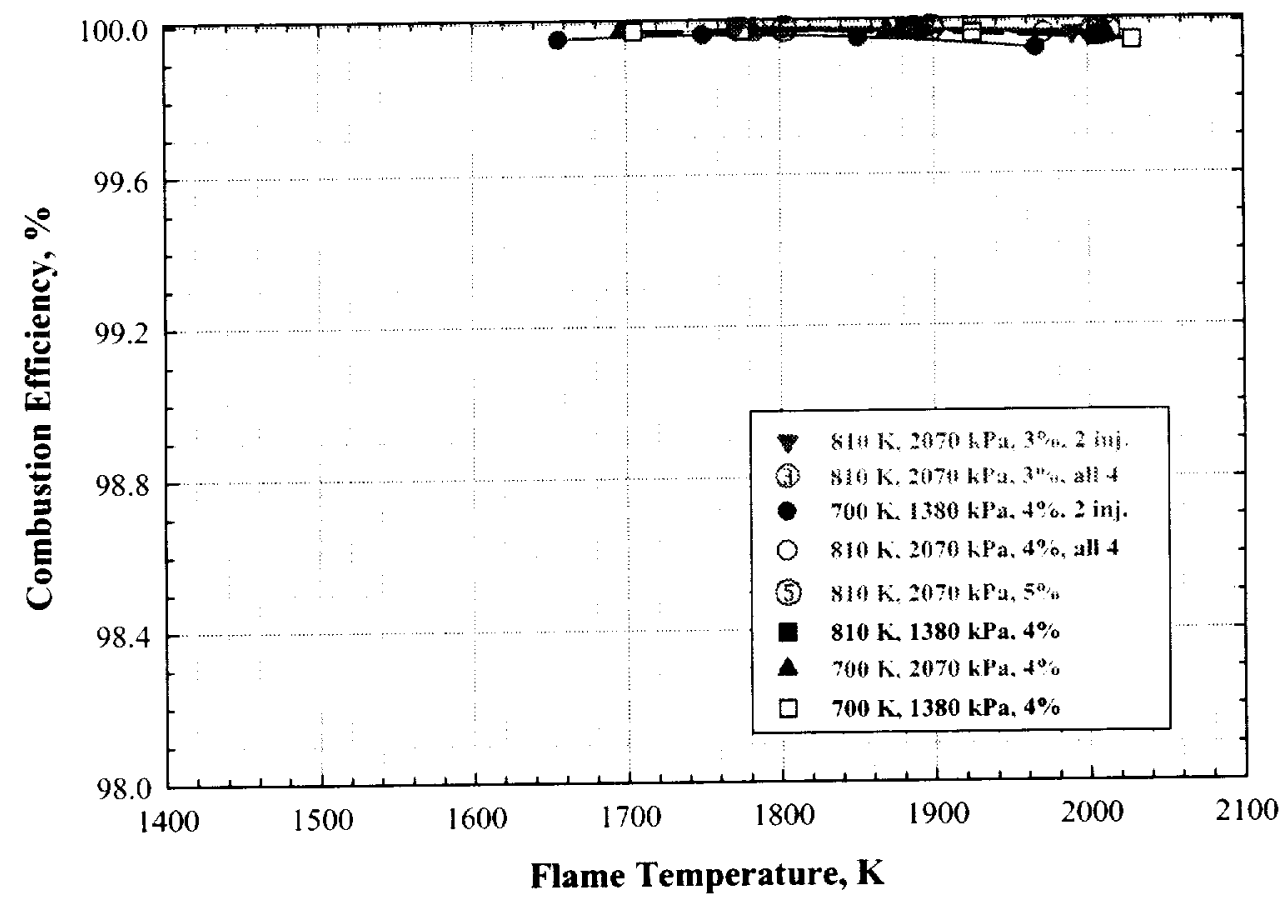

Figure 8g. - Configuration G

Figure 8. - Combustion efficiency as a function of flame temperature for each configuration 

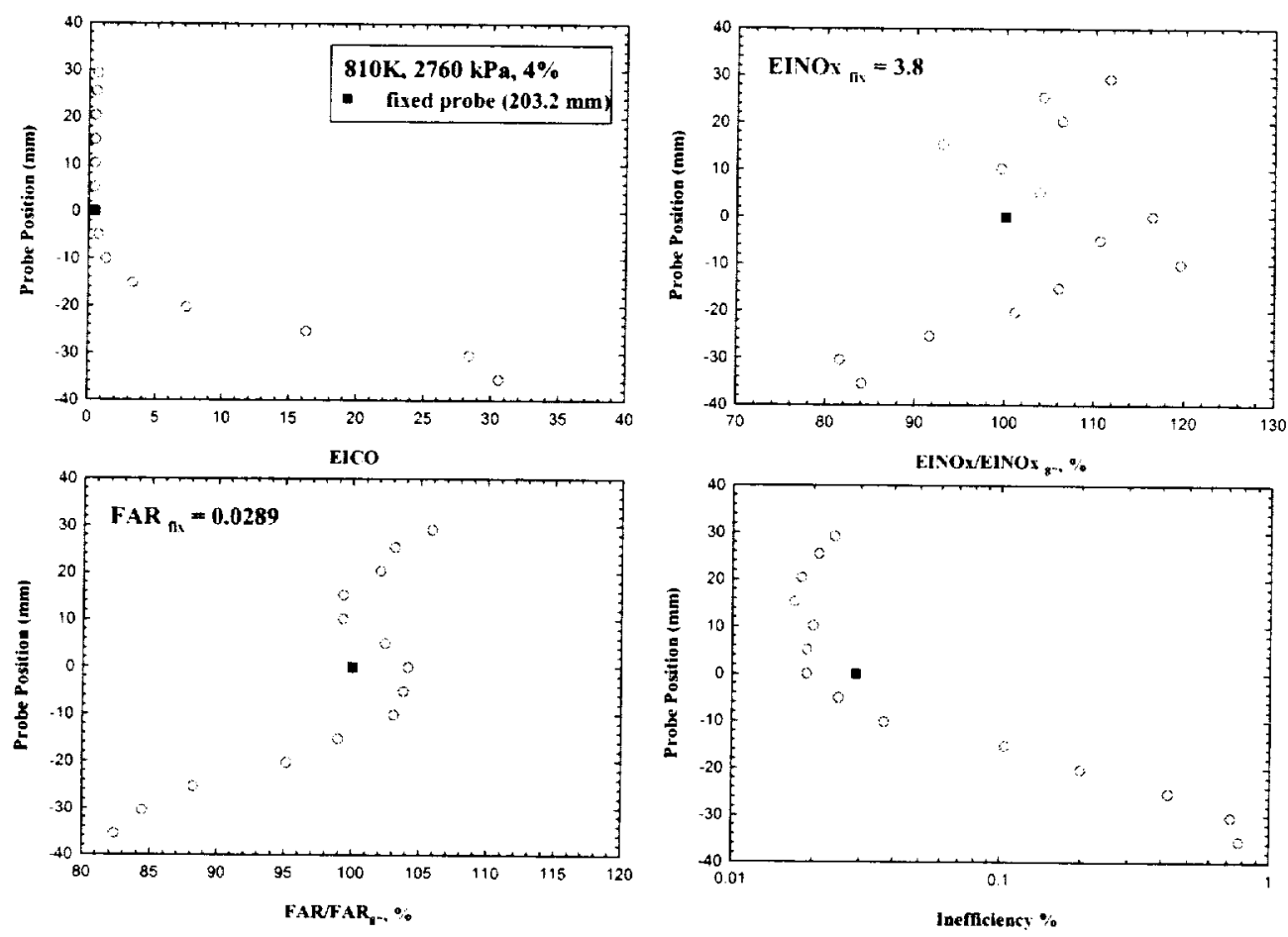

Figure 9a. Configuration $A$
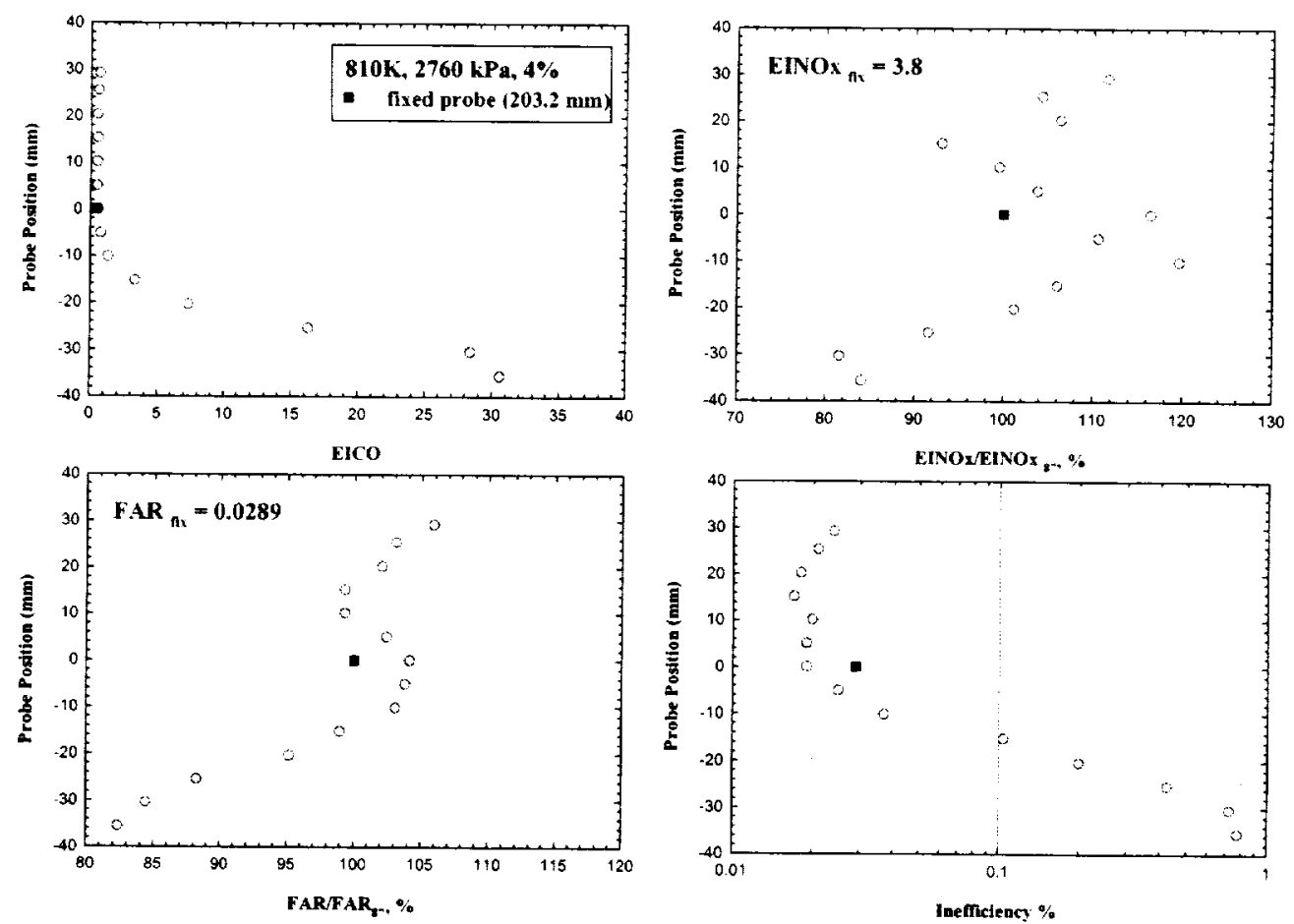

Figure 9b. Configuration B

Figure 9. - Radial profiles of emissions, vertical profile at $102 \mathrm{~mm}$ downstream of injector 

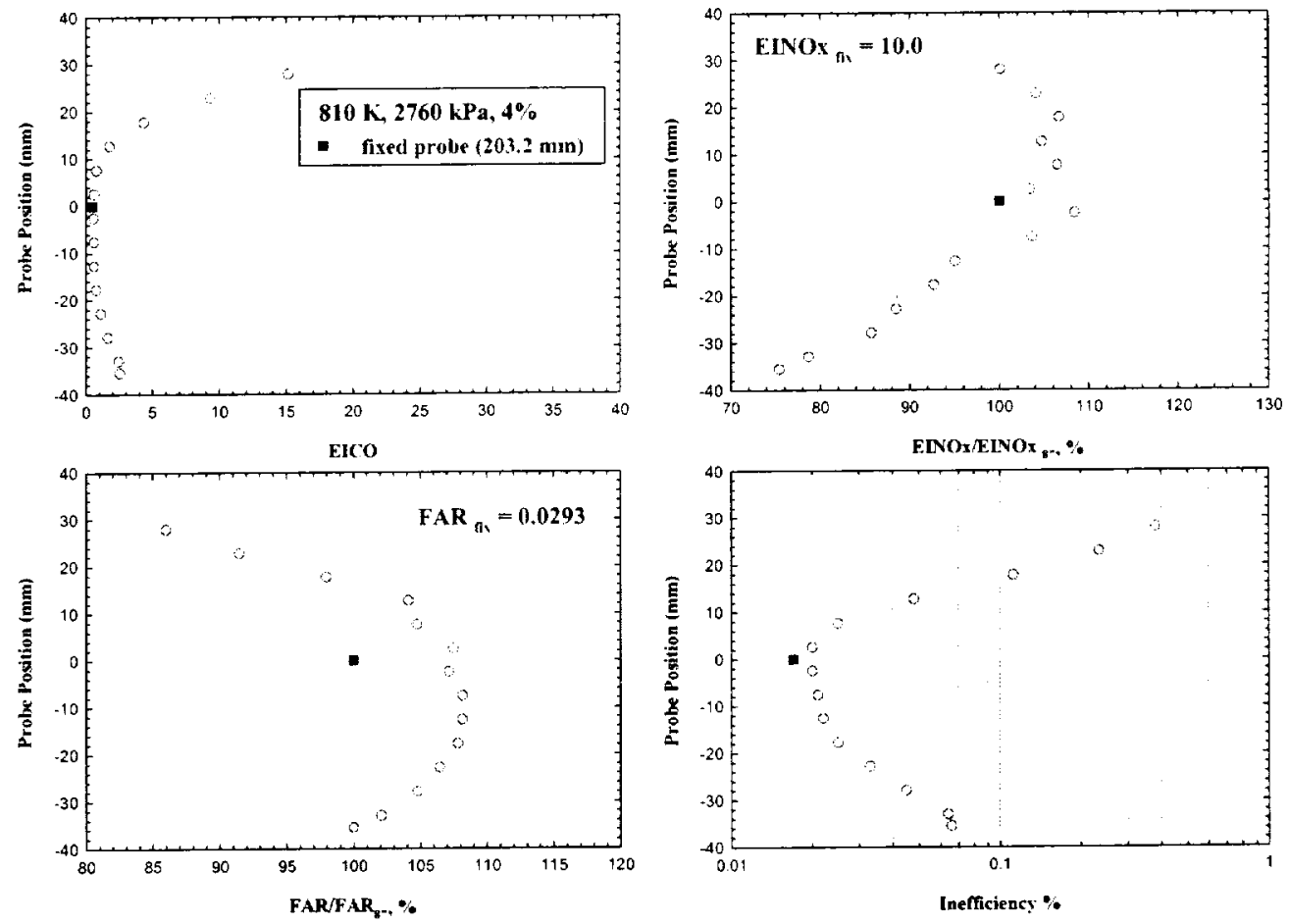

Figure 9c. Configuration $\mathrm{C}$

Figure 9. - Radial profiles of emissions, vertical profile at $102 \mathrm{~mm}$ downstream of injector 


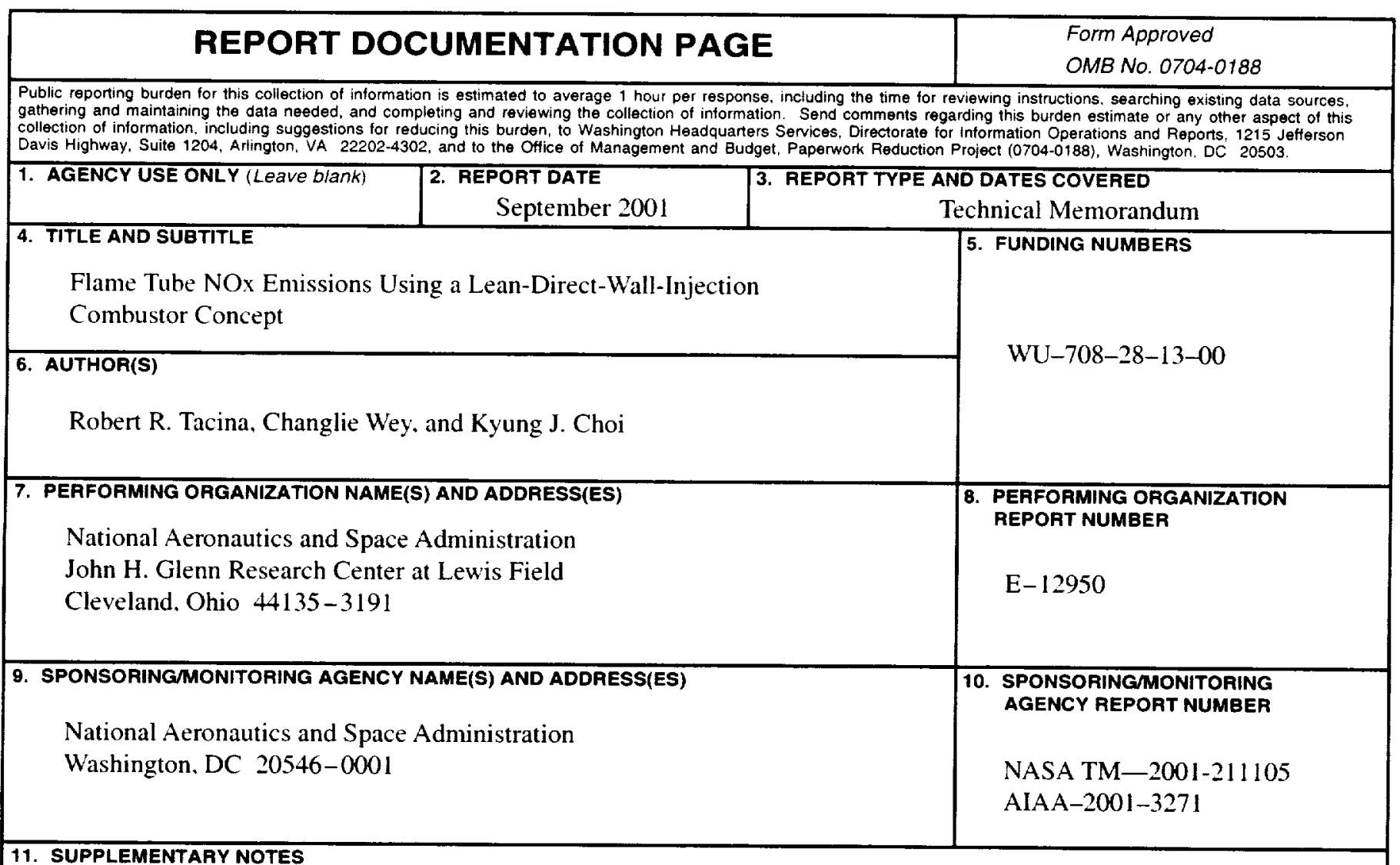

\section{SUPPLEMENTARY NOTES}

Prepared for the 37th Joint Propulsion Conference and Exhibit cosponsored by the AIAA, ASME, SAE, and ASEE. Salt Lake City, Utah, July 8-1 1, 2001. Robert R. Tacina, NASA Glenn Research Center; Changlie Wey, QSS Group. Inc., 2000 Aerospace Parkway, Brook Park. Ohio 44142; and Kyung J. Choi, Drexel University, 3141 Chestnut Street, Philadelphia, Pennsylvania 19104-2816. Responsible person, Robert R. Tacina, organization code 5830, 216-433-3588.

12a. DISTAIBUTIONAVAILABILITY STATEMENT 12b. DISTRIBUTION CODE

Unclassified - Unlimited

Subject Category: 07

Distribution: Nonstandard

Available electronically at http//gltrs.grc,nasalgov/GLTRS

This publication is available from the NASA Center for AeroSpace Information. 301-621-0390.

13. ABSTRACT (Maximum 200 words)

A low-NOx emissions combustor concept has been demonstrated in flame tube tests. A lean-direct injection concept was used where the fuel is injected directly into the flame zone and the overall fuel-air mixture is lean. In this concept the air is swirled upstream of a venturi section and the fuel is injected radially inward into the air stream from the throat section using a plain-orifice injector. Configurations have two-, four-, or six-wall fuel injectors and in some cases fuel is also injected from an axially located simplex pressure atomizer. Various orifice sizes of the plain-orifice injector were evaluated for the effect on NOx. Test conditions were inlet temperatures up to $810 \mathrm{~K}$, inlet pressures up to $2760 \mathrm{kPa}$, and flame temperatures up to $2100 \mathrm{~K}$. A correlation is developed relating the NOx emissions to inlet temperature, inlet pressure, fuel-air ratio and pressure drop. Assuming that 15 percent of the combustion air would be used for liner cooling and using an advanced engine cycle, for the best configuration, the NOx emissions using the correlation is estimated to be $<75$ percent of the 1996 ICAO standard.

14. SUBJECT TERMS

Gas turbine combustor emissions; NOx emissions; Lean-direct injection

\begin{tabular}{|c|c|}
\hline $\begin{array}{c}\text { 17. SECURITY CLASSIFICATION } \\
\text { OF REPORT } \\
\text { Unclassified }\end{array}$ & $\begin{array}{c}\text { 18. SECURITY CLASSIFICATION } \\
\text { OF THIS PAGE } \\
\text { Unclassified }\end{array}$ \\
\hline
\end{tabular}

NSN 7540-01-280-5500

19. SECURITY CLASSIFICATION OF ABSTRACT Unclassified 31

\section{NUMBER OF PAGES}

16. PRICE CODE 20. LIMITATION OF ABSTRACT 

